\section{OPEN ACCESS}

Edited by:

Cristina Bonorino,

Federal University of Health Sciences

of Porto Alegre, Brazil

Reviewed by:

Lewis Zhichang Shi,

University of Alabama at Birmingham,

United States

Gabriella Pietra,

Università di Genova, Italy

${ }^{*}$ Correspondence:

Si-Yi Chen

si-yi.chen@med.usc.edu Andrew B. Sharabi

sharabi@ucsd.edu

tThese authors have contributed equally to this work

Specialty section:

This article was submitted to

$T$ Cell Biology,

a section of the journal

Frontiers in Immunology

Received: 23 October 2018

Accepted: 22 February 2019

Published: 18 March 2019

Citation:

Guram K, Kim SS, Wu V, Sanders $P D$

Patel S, Schoenberger SP,

Cohen EEW, Chen S-Y and

Sharabi AB (2019) A Threshold Model

for T-Cell Activation in the Era of

Checkpoint Blockade Immunotherapy.

Front. Immunol. 10:491.

doi: 10.3389/fimmu.2019.00491

\title{
A Threshold Model for T-Cell Activation in the Era of Checkpoint Blockade Immunotherapy
}

Kripa Guram ${ }^{1 \dagger}$, Sangwoo S. Kim ${ }^{1 \dagger}$, Victoria $\mathrm{Wu}^{2}$, P. Dominick Sanders ${ }^{1}$, Sandip Patel ${ }^{3}$, Stephen P. Schoenberger ${ }^{3,4}$, Ezra E. W. Cohen ${ }^{2}$, Si-Yi Chen ${ }^{5 *}$ and Andrew B. Sharabi ${ }^{1,2 *}$

\footnotetext{
${ }^{1}$ Department of Radiation Medicine and Applied Sciences, San Diego Moores Cancer Center, University of California, San Diego, San Diego, CA, United States, ${ }^{2}$ Moores Comprehensive Cancer Center, University of California, San Diego, San Diego, CA, United States, ${ }^{3}$ Division of Hematology and Oncology, Center for Personalized Cancer Therapy, San Diego Moores Cancer Center, University of California, San Diego, San Diego, CA, United States, ${ }^{4}$ Laboratory of Cellular Immunology, La Jolla Institute for Allergy and Immunology, La Jolla, CA, United States, ${ }^{5}$ Department of Molecular Microbiology and Immunology, Norris Comprehensive Cancer Center, University of Southern California, Los Angeles, CA, United States
}

Continued discoveries of negative regulators of inflammatory signaling provide detailed molecular insights into peripheral tolerance and anti-tumor immunity. Accumulating evidence indicates that peripheral tolerance is maintained at multiple levels of immune responses by negative regulators of proinflammatory signaling, soluble anti-inflammatory factors, inhibitory surface receptors \& ligands, and regulatory cell subsets. This review provides a global overview of these regulatory machineries that work in concert to maintain peripheral tolerance at cellular and host levels, focusing on the direct and indirect regulation of $\mathrm{T}$ cells. The recent success of checkpoint blockade immunotherapy (CBI) has initiated a dramatic shift in the paradigm of cancer treatment. Unprecedented responses to $\mathrm{CBI}$ have highlighted the central role of $\mathrm{T}$ cells in both anti-tumor immunity and peripheral tolerance and underscored the importance of $T$ cell exhaustion in cancer. We discuss the therapeutic implications of modulating the negative regulators of $T$ cell function for tumor immunotherapy with an emphasis on inhibitory surface receptors \& ligands - central players in T cell exhaustion and targets of checkpoint blockade immunotherapies. We then introduce a Threshold Model for Immune Activation-the concept that these regulatory mechanisms contribute to defining a set threshold of immunogenic (proinflammatory) signaling required to elicit an anti-tumor or autoimmune response. We demonstrate the value of the Threshold Model in understanding clinical responses and immune related adverse events in the context of peripheral tolerance, tumor immunity, and the era of Checkpoint Blockade Immunotherapy.

Keywords: negative regulator, antigen presentation attenuator, threshold model, checkpoint blockade, immunotherapy, PD-1, CTLA-4, T cell exhaustion 


\section{INTRODUCTION}

Over the past decades, an increasing body of genetic studies on the negative regulation of proinflammatory signaling has demonstrated the essential role of negative regulators of proinflammatory signal transduction pathways in the maintenance of peripheral tolerance. Genetic deficiency in one of these negative regulators often results in severe inflammation and autoimmune pathologies in both mice and humans (Tables 1, 2). These genetic studies have provided insights into the nature of the signals, molecular processes, and regulatory cell subsets for maintaining peripheral tolerance. Peripheral tolerance is maintained at multiple levels of immune responses, including (a) antigen presentation, (b) lymphocyte activation and effector function, and (c) peripheral tissues. Each level of immune responses is regulated synergistically by employing diverse regulatory mechanisms, including negative regulators of proinflammatory signaling, soluble anti-inflammatory factors, inhibitory surface receptors \& ligands, and regulatory cell subsets (Figure 1). These interrelated, non-redundant regulatory machineries work in concert to ensure an appropriate innate and adaptive immune response that is sufficient to clear invading pathogens, while preventing toxicity from over activation or pathological autoimmunity.

Naïve $\mathrm{CD} 8^{+} \mathrm{T}$ cells that encounter antigens during immune challenge (e.g., acute infection) set forth a cell-intrinsic program that drives them to expand and differentiate into cytotoxic effector cells that control and eventually clear the pathogen (53). At peak response, these effector $\mathrm{T}$ cells secrete high amounts of cytokines [interferon- $\gamma$ (IFN $\gamma)$ and tumor necrosis factor (TNF)] and cytolytic molecules (granzymes and perforin). Subsequently, if the antigenic source has been eliminated, most of these effector T cells undergo apoptosis, and a few survive and become central memory and effector memory $\mathrm{T}$ cells $(54,55)$. While this differentiation process is tightly controlled, changes in the nature, context, and duration of antigen exposure can alter the process and lead to $\mathrm{T}$ cell dysfunction, unresponsiveness, and/or death. Observed phenotypic and functional features define $\mathrm{T}$ cell dysfunction as exhaustion, tolerance, or anergy, and characterizing these cellular and molecular features can define strategies that can overcome their dysfunction. $\mathrm{T}$ cell dysfunction has been well-studied in infections associated with high viral replication, like LCMV clone 13, hepatitis $\mathrm{C}$ virus, hepatitis B virus, and HIV, but also in bacterial and parasitic infections and cancer (56-60). Here, we discuss the various states of $\mathrm{T}$ cell dysfunction, focusing on the more extensively defined characteristics of tolerance and exhaustion in tumor associated $\mathrm{T}$ cells.

In connecting these diverse regulatory mechanisms and providing a global overview of $\mathrm{T}$ cell dysfunction, we introduce the Threshold Model for Immune Activation-the concept that an individual's immune system has an inherent threshold of immunogenic signaling required to elicit either an antitumor immune response, auto-immune response, or both. This threshold is determined by the interplay of these negative regulators and their stimulatory counterparts, which work together to modulate the functional state of individual immune cells and achieve immune homeostasis. Consideration of the delicate balance of $\mathrm{T}$ cell activation and exhaustion/tolerance required for homeostasis is critical as we work toward developing immunotherapies that maximize anti-tumor function while minimizing detrimental immunological pathology. As the decades of research in immunology and cancer biology are finally coming to fruition in the clinic, this model provides a conceptual framework to orient ourselves in the Era of Checkpoint Blockade.

\section{THE THRESHOLD MODEL FOR IMMUNE ACTIVATION}

A vast number of positive and negative regulatory factors modulate the immune system and work in concert to achieve immune homeostasis (61-65). Regulation of the immune system is exceedingly complex, involving the interplay of these diverse regulatory mechanisms at multiple levels. Immune regulation also varies greatly between individuals, and is likely a major factor in differential outcomes and adverse effects seen in patients treated with cancer immunotherapy (66). As described here the Threshold Model provides a straightforward context for understanding immune activation, autoimmunity, and antitumor immunity in order to conceptualize the types of responses we have seen in patients treated with CBI:

For an individual patient, a plotted horizontal line represents their immune system's "threshold" of immune activation (Figure 2). The threshold represents the level of immunogenic stimulation required to elicit an immune response, determined by the sum of the negative regulatory mechanisms that work at all levels of the immune system. Stimulation of the immune system to any level below this threshold may still activate individual cells of the immune system, but is insufficient to overcome these regulatory mechanisms and mount an effective systemic immune response.

In a given patient, there are various events that stimulate or inhibit their baseline tumor or host immunogenicity. We can plot the level of immunogenicity over time as sinusoidal "immunogenicity curves" that represent different types of baseline immunogenicity and natural variations in baseline tumor or host immunogenicity due to host and environmental factors (Figure 2). These curves are determined by a multitude of factors, including the patient's genetics, environmental exposures, health, diet, as well as positive and negative feedback mechanisms themselves. Notably, people who are genetically predisposed to autoimmune conditions would have a baseline autoimmune immunogenicity curve with higher peaks than those without this risk factor. For instance, a patient with systemic lupus erythematosus may live many years before developing full blown autoimmunity due to some triggering event which results in crossing of the threshold (67).

At rest, the peak of the immunogenicity curve lies below the threshold of activation, and antigen specific immune responses are not promoted (Figure 2). When the immune system is stimulated beyond the threshold level, such as due to presence of a bacteria, virus, or other exogenous factor an antigen specific immune response occurs (Figure 2). Once the 
TABLE 1 | Representative negative regulators of TLR and related signal transduction pathways.

\begin{tabular}{|c|c|c|c|c|c|c|}
\hline & $\begin{array}{l}\text { Negative } \\
\text { regulators }\end{array}$ & Example & Expression & Possible mechanism & Phenotype of genetic deficient mice & References \\
\hline \multirow{4}{*}{$\begin{array}{l}\text { Ubiquitin E3 } \\
\text { ligases/SUMO }\end{array}$} & \multirow{3}{*}{$\begin{array}{l}\text { E3 ubiquitin } \\
\text { ligases } \\
\text { (hundreds of } \\
\text { members) }\end{array}$} & TRIAD3A & Constitutive & Ubiquitinates TLRs for degradation & NA & $(1)$ \\
\hline & & SOCS1 & Inducible & $\begin{array}{l}\text { Ubiquitinates Mal for degradation, in } \\
\text { addition to inhibiting JAK/STAT }\end{array}$ & $\begin{array}{l}\text { Neonatal lethality, severe inflammation of } \\
\text { multiple organs, hypersensitivity to LPS, } \\
\text { hy peractivated DCs, M } \Phi \text {, and T cells }\end{array}$ & $(2)$ \\
\hline & & A20 & Inducible & $\begin{array}{l}\text { Ubiquitinates/deubiquitinates RIP and } \\
\text { TRAF6 for degradation }\end{array}$ & $\begin{array}{l}\text { Neonatal death, severe inflammation, } \\
\text { cachexia and hypersensitivity to LPS }\end{array}$ & $(3-5)$ \\
\hline & SUMO (4) & SUMO1 & Constitutive & SUMOylate and stabilize ІкB & NA (not available) & $(6,7)$ \\
\hline \multirow[t]{6}{*}{$\begin{array}{l}\text { Inhibitory } \\
\text { isoforms }\end{array}$} & IRAK isoforms & IRAK-M & Inducible & $\begin{array}{l}\text { Prevents dissociation of IRAK-IRAK4 } \\
\text { and formation of IRAK-TRAF6 }\end{array}$ & $\begin{array}{l}\text { No gross abnormality, hypersensitive to } \\
\text { LPS, hyperactivated M } \phi\end{array}$ & (8) \\
\hline & MyD88s & & Inducible & Inhibits MyD88 & NA & (9) \\
\hline & ST2 & & Inducible & $\begin{array}{l}\text { Inhibits TLR4 signaling by } \\
\text { sequestrating MyD88 and Mal }\end{array}$ & $\begin{array}{l}\text { No obvious abnormalities, fail to develop } \\
\text { endotoxin tolerance, reduced production } \\
\text { of } \mathrm{TH} 2 \text { cytokines }\end{array}$ & $(10,11)$ \\
\hline & SIGIRR & & $\begin{array}{l}\text { Constitutive, } \\
\text { reduced by } \\
\text { stimulation }\end{array}$ & $\begin{array}{l}\text { Binds and inhibits TLR4-IL-1R } \\
\text { signaling molecules IRAK and TRAF6 }\end{array}$ & $\begin{array}{l}\text { No obvious abnormalities, hypersensitive } \\
\text { to LPS, hyperactivated M } \phi \text { and T cells }\end{array}$ & $(12)$ \\
\hline & RP105 & & Constitutive & $\begin{array}{l}\text { Inhibits TLR4 binding with microbial } \\
\text { products }\end{array}$ & NA & $(13)$ \\
\hline & sTLR2/4 & & Constitutive & Antagonists of TLR2 and 4 & NA & $(14,15)$ \\
\hline \multirow{2}{*}{$\begin{array}{l}\text { Inhibitory } \\
\text { components of } \\
\text { signaling } \\
\text { complexes }\end{array}$} & $\operatorname{l\kappa B}(3)$ & $\mid \kappa B \alpha$ & Constitutive & Retains NF-кB in the cytosol & $\begin{array}{l}\text { Neonatal death, severe dermatitis and } \\
\text { inflammation }\end{array}$ & $(16,17)$ \\
\hline & $\mathrm{IKK} \alpha$ & & Constitutive & $\begin{array}{l}\text { Phosphorylates RelA and c-Rel, } \\
\text { resulting in accelerated turnover }\end{array}$ & $\begin{array}{l}\text { Neonatal death, enhanced sensitivity to } \\
\text { LPS, hyperactivated M } \phi\end{array}$ & $(17,18)$ \\
\hline \multirow[t]{4}{*}{$\begin{array}{l}\text { Transcription } \\
\text { factors }\end{array}$} & \multirow[t]{3}{*}{$\begin{array}{l}\text { Fox (>100 } \\
\text { members) }\end{array}$} & Foxj1, & $\begin{array}{l}\text { Constitutive, } \\
\text { reduced by } \\
\text { stimulation }\end{array}$ & Transcription activator of І $к B \beta$ & $\begin{array}{l}\text { Embryonic lethality, chimerization of } \\
\text { Rag }^{-/-} \text {mice results in severe } \\
\text { inflammation, hyperactivated T cells }\end{array}$ & (19) \\
\hline & & FoxOa3, & $\begin{array}{l}\text { Constitutive, } \\
\text { reduced by }\end{array}$ & Transcription activator of $І_{\kappa} \mathrm{B} \beta / \mathrm{I}_{\kappa} \mathrm{B} \xi$ & $\begin{array}{l}\text { No gross abnormality, multiorgan } \\
\text { inflammation, lymphoproliferation }\end{array}$ & $(20)$ \\
\hline & & Foxp3 & $\begin{array}{l}\text { stimulation } \\
\text { Constitutive in } \\
\text { CD25 }{ }^{+} \text {CD4 }{ }^{+} \\
T \text { cells }\end{array}$ & $\begin{array}{l}\text { Transcription repressor of } \\
\text { proinflammatory cytokines }\end{array}$ & $\begin{array}{l}\text { Neonatal death, inflamed skin (scurfy), } \\
\text { severe inflammation of multiple organs, } \\
\text { fatal IPEX syndrome in humans }\end{array}$ & $(21-24)$ \\
\hline & Twist $1 / 2$ & & Inducible & $\begin{array}{l}\text { Inhibits NF-кB binding to cytokine } \\
\text { promoters }\end{array}$ & $\begin{array}{l}\text { Neonatal death, severe inflammation, } \\
\text { cachexia, and hypersensitivity to tnf }\end{array}$ & $(25)$ \\
\hline \multirow[t]{2}{*}{$\begin{array}{l}\text { Phosphatases } \\
\text { (PTP) }\end{array}$} & \multirow[t]{2}{*}{$\begin{array}{l}\text { MKP (11 } \\
\text { members) }\end{array}$} & MKP1 & Inducible & Inhibits JNK and p38 pathways & $\begin{array}{l}\text { No gross abnormality Hypersensitive to } \\
\text { Ips, hyperactivated } \mathrm{m} \phi\end{array}$ & $(26,27)$ \\
\hline & & MKP5 & Inducible in $\mathrm{M} \phi$, & Inhibits JNK pathway & $\begin{array}{l}\text { No gross abnormality, hypersensitive to } \\
\text { Ips, hyperactivated m } \phi \text { and T cells }\end{array}$ & $(28)$ \\
\hline \multirow[t]{4}{*}{$\begin{array}{l}\text { Other } \\
\text { mechanisms }\end{array}$} & Dok-1/2 & & Constitutive & $\begin{array}{l}\text { Suppresses Erk activation of TLR4 } \\
\text { signaling }\end{array}$ & $\begin{array}{l}\text { No gross abnormality, hypersensitive to } \\
\text { LPS, hyperactivated } \mathrm{M} \phi \text { and T cells }\end{array}$ & $\begin{array}{l}(29) \\
(30)\end{array}$ \\
\hline & $\beta$-Arrestin-1/2 & & Constitutive & 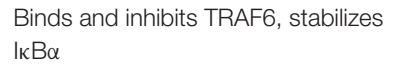 & Hypersensitive to LPS, hyperactivated M $\phi$ & $(31-33)$ \\
\hline & TOLLIP & & Constitutive & Suppresses IRAK1 & NA & (34) \\
\hline & NOD2 & & Constitutive & $\begin{array}{l}\text { Inhibits TLR2-drived activation of } \\
N F-\kappa B \text { and } T_{H^{1}} \text { responses }\end{array}$ & $\begin{array}{l}\text { Inflammatory diseases such as colitis, } \\
\text { Crohn's disease in humans }\end{array}$ & $(35,36)$ \\
\hline
\end{tabular}

threshold is crossed positive feedback loops and autocrine and paracrine signaling pathways naturally induce rapid expansion and propagation of antigen specific T-cells or B-cells. Negative regulatory mechanisms still play a role in modulating the extent and duration of this response, and eventually bring the immune system back to homeostasis or a new baseline with formation of memory responses.

The first approach to cancer immunotherapy was to enhance positive stimulation of the immune system with bacterial preparations and subsequently cytokines or vaccines to drive anti-tumor immunity (68). This effectively increased the peaks of the baseline tumor immunogenicity curve in attempt to stimulate beyond the threshold. However, due to the powerful negative regulatory mechanisms we will discuss this approach was rarely successful and the threshold for immunity was likely higher than could be reached with these agonist agents alone in most cases.

The approach used with Checkpoint Blockade Immunotherapy (CBI) is to directly inhibit the negative 
TABLE 2 | Representative negative regulators of cytokine receptor signaling pathways.

\begin{tabular}{|c|c|c|c|c|c|}
\hline Negative regulator & Example & Expression & $\begin{array}{l}\text { Possible mechanism on } \\
\text { immune responses }\end{array}$ & Phenotype of genetic deficient mice & References \\
\hline \multirow[t]{3}{*}{ SOCS (8 members) } & SOCS1 & Inducible & $\begin{array}{l}\text { Blocks JAK-Stat interaction and } \\
\text { ubiquitinates JAK for } \\
\text { degradation }\end{array}$ & $\begin{array}{l}\text { Neonatal lethality, severe inflammation of multiple } \\
\text { organs, hypersensitivity to LPS, hyperactivated DCs, M } \Phi \\
\& T \text { cells }\end{array}$ & $(37-41)$ \\
\hline & SOCS2 & Inducible & $\begin{array}{l}\text { Inhibits the signaling of growth } \\
\text { hormone and cytokines }\end{array}$ & $\begin{array}{l}\text { Gigantism, hypersensitive to microbial stimuli, } \\
\text { hyperactivated DCs, }\end{array}$ & $(42,43)$ \\
\hline & SOCS3 & Inducible & $\begin{array}{l}\text { Selectively inhibits IL-6 receptor } \\
\text { subunit } \\
\text { gp130-mediated signaling }\end{array}$ & $\begin{array}{l}\text { Embryonic lethality due to placental defects, mice with a } \\
\text { conditional deletion in } М \Phi \text { and neutrophils are } \\
\text { hyposensitive to LPS }\end{array}$ & (44-46). \\
\hline PIAS (4 members) & PIAS1 & Constitutive & $\begin{array}{l}\text { Blocks DNA binding of STATs, } \\
\text { sumoylates STATs to inhibit their } \\
\text { transcription, blocks the DNA } \\
\text { binding of p65 to suppress } \\
\text { NF-кB }\end{array}$ & $\begin{array}{l}\text { No gross abnormality, hypersensitivity to LPS, } \\
\text { hyperactivated M } \Phi\end{array}$ & $(47,48)$ \\
\hline \multirow[t]{2}{*}{ PTP (107 members) } & SHP1 & Constitutive & $\begin{array}{l}\text { Dephosphorylates cytokine } \\
\text { receptor signaling molecules }\end{array}$ & Motheaten (dermatitis) phenotype & $(49,50)$ \\
\hline & SHP2 & Constitutive & $\begin{array}{l}\text { Dephosphorylates cytokine } \\
\text { receptor signaling molecules }\end{array}$ & Embryonic lethality due to severe hematopoietic defects & (51) \\
\hline SLIM & & Constitutive & $\begin{array}{l}\text { Ubiquitinates STAT1 and STAT4 } \\
\text { for degradation }\end{array}$ & $\begin{array}{l}\text { No gross abnormality, enhanced IFN production by } T \\
\text { cells }\end{array}$ & $(52)$ \\
\hline
\end{tabular}

\section{Peripheral tolerance maintained by multiple negative regulatory mechanisms controlling multiple levels and phases of immune responses}

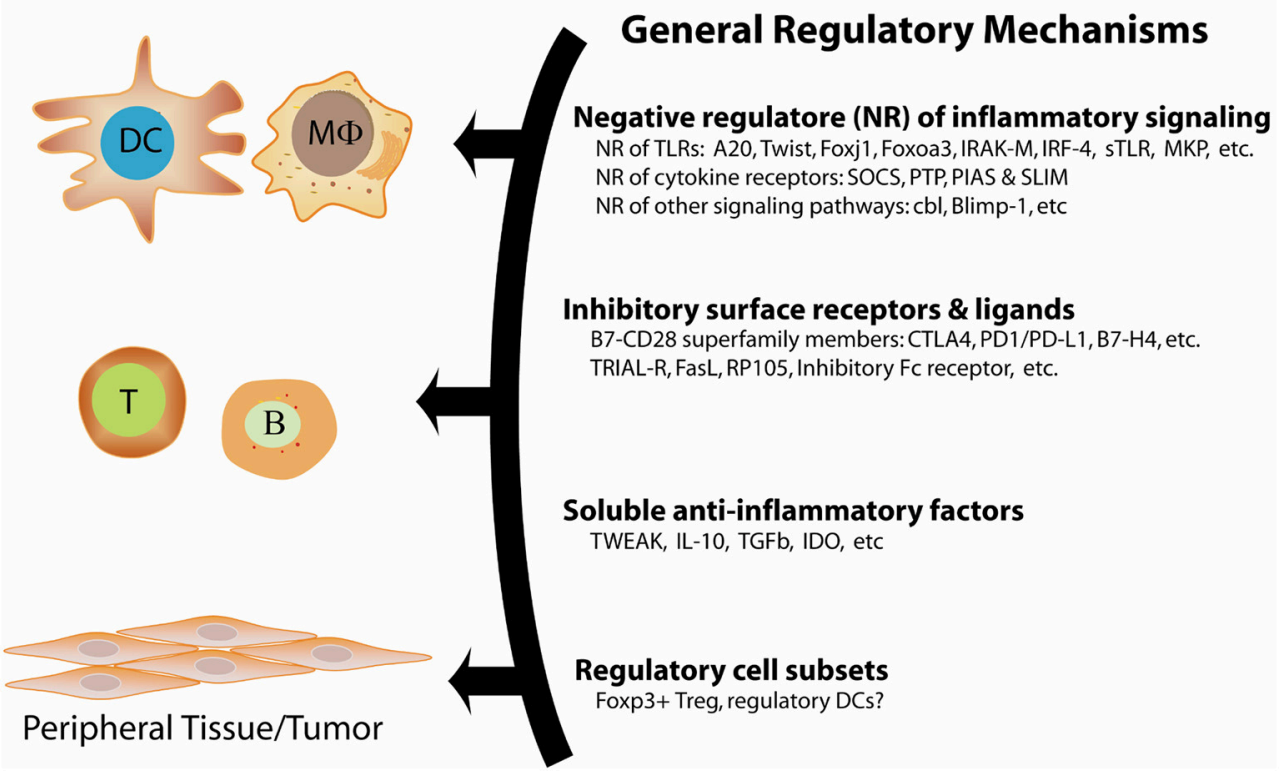

FIGURE 1 | General regulatory mechanisms for the maintenance of peripheral tolerance. Peripheral tolerance is maintained by at least four interrelated, non-redundant regulatory mechanisms that work in concert to negatively regulate multiple levels of immune responses, including antigen presentation, lymphocyte activation and effector function, and peripheral tissues.

regulatory mechanisms and disable the major brakes on the immune system, including the CTLA- 4 or PD-1/PD-L pathways $(69,70)$. This approach effectively lowers the immune threshold and decreases the amount of stimulation required to elicit an immune response. Dual agent checkpoint blockade would effectively lower the threshold for immune activation even further. We illustrate the possible outcomes of lowering the immune threshold via CBI in Figure 2. The activity of single agent checkpoint blockade alone and the concomitant increase in objective response rates and immune related toxicity with dual agent checkpoint blockade strongly support this threshold model (71). Interestingly, the activation of an anti-tumor immune 


\section{A Threshold Model for Immune Activation}
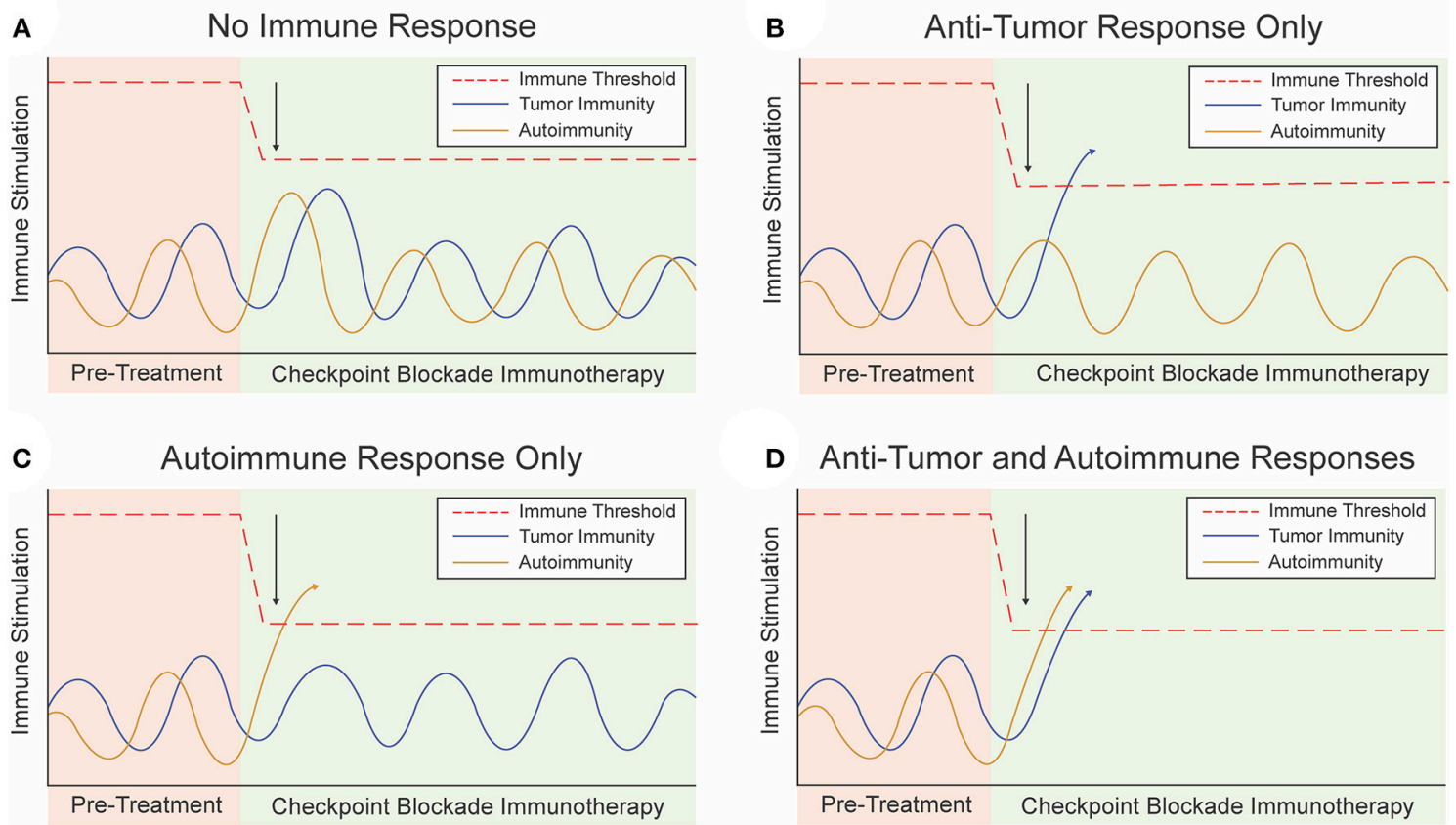

FIGURE 2 | A threshold model for immune activation. (A) Checkpoint Blockade Immunotherapy (CBI) lowers the threshold for immune activation but not enough to trigger an immune response. (B) CBI lowers the threshold for immune activation to trigger an anti-tumor immune response but not an auto-immune response. (C) Baseline immunity to self antigens is higher than immunity to tumor associated antigens. CBI lowers the threshold to induce an auto-immune response but no anti-tumor immune response or immune-related adverse event. (D) Single agent or dual agent CBI lowers the threshold for immune activation to trigger an anti-tumor immune response and an auto-immune response or immune-related adverse event.

response may result in development adaptive resistance or emergence of counter-regulatory mechanisms which attempt to subvert this response or effectively raise the threshold back up (72). This could have important implications for maintenance therapy or re-induction of immune responses during re-challenge with CBI after an initial course.

Another important point derived from this model is the concept that more stimulation is not necessarily better for immune responses. In fact excessive stimulation in many cases has a paradoxical response and leads to inhibition or activation induced cell death (73). The immune system must constantly attempt to balance under activation (risk of disseminated infection) and over activation (risk of auto-immunity or cytokine storm). Thus, the threshold model would predict that in the absence of negative regulation (lowest threshold) only a minor amount of positive stimulation would be required to elicit an immune response. Indeed, this is evidenced by the activity of single agent checkpoint blockade alone, where stimulatory factors already present in the tumor microenvironment or lymphoid organs are sufficient to activate potent anti-tumor immunity without the need for exogenous proinflammatory or agonist factors $(69,70)$. The clinical implication of this being that in the era of checkpoint blockade as we return to testing proimmunogenic agonist therapies less drug may be needed for optimal induction of immune responses in certain circumstances.
In this article we will first highlight the immunologic principles governing negative regulation of immune cells, then more closely examine the role of $\mathrm{T}$ cell regulation and $\mathrm{T}$ cell exhaustion in cancer. We apply the threshold model to better understand how to overcome these regulatory mechanisms and induce effective anti-tumor immune responses in the setting of checkpoint blockade immunotherapy.

\section{CHARACTERISTICS OF IMMUNE TOLERANCE}

\section{Negative Regulation at the Level of Antigen Presenting Cells}

The first level of regulation of peripheral $\mathrm{T}$ cell tolerance involves the control of antigen presentation. Antigen presentation initiates $\mathrm{T}$ cell activation, and antigen-presenting cells (APCs), such as dendritic cells (DCs) and macrophages (M $\Phi)$, play a critical role in stimulating immune responses as well as maintaining peripheral tolerance $(74,75)$. Innate immunity activated by Toll-like receptor (TLR) signaling is crucial in the detection of invading pathogens and the activation of adaptive immunity (76). Members of the TLR family detect conservative microbial molecules, including lipopolysaccharide (LPS), bacterial lipoproteins, flagellin, unmethylated CpG 
DNA, and viral RNA (61, 63). After ligand binding, TLRs dimerize and undergo the conformational change required for recruitment of downstream signaling molecules, activating MyD88-dependent and MyD88-independent pathways. The subsequent activation of nuclear factor- $\kappa \mathrm{B}(\mathrm{NF}-\kappa \mathrm{B})$ and mitogenactivated protein (MAP) kinases leads to the expression of a large number of proinflammatory molecules, such as costimulatory molecules and cytokines, for the induction of adaptive immunity $(61,63)$. The stimulatory potency of TLR signaling in the activation of innate and adaptive immunity is reflected in the complicated negative regulation of TLR signaling at multiple points (Figures 3, 4). An excellent recent review by Liew et al. (65) describes many of these negative regulators, including intracellular IRAK-M, MyD88s, PI3K, TOLLIP, A20, TRIAD3A, and NOD2, soluble TLR2/4, membrane-bound SIGIRR, and ST2.

Much of the study on innate and adaptive immunity has been focused on the identification and characterization of proinflammatory signal receptors and regulators $(61,63)$. However, during the last two decades, an increasing number of negative regulators that inhibit proinflammatory signal transduction in APCs and other immune cells have been discovered (Tables 1, 2). These negative regulators in APCs function as antigen presentation attenuators (APAs) to control the strength and duration of proinflammatory signaling in APCs in order to set the threshold of antigen presentation (tolerogenic state), regulate the magnitude and duration of antigen presentation, and prevent acute toxic innate immune hyper-response (endotoxin shock) and pathological autoimmunity. Recent studies indicate that cytokine signaling in APCs is critical for antigen presentation (77-80) and is also tightly regulated at multiple points by negative regulators $(62,64)$.

Additionally, certain subsets of APCs function to hinder immune activation and promote tolerance. Tolerogenic DCs are usually immature DCs, which have low levels of co-stimulatory molecules $(75,81,82)$. Immature DCs can induce tolerance through the induction of regulatory $\mathrm{T}$ cells that suppress immune responses by secreting anti-inflammatory cytokines such as IL-10 and TGF $\beta$ (83). Tolerogenic DCs can also be generated ex vivo by treating them with TGF- $\beta$ or a variety of immunosuppressive drugs. A population of DCs (CD11c low, $\mathrm{CD} 45 \mathrm{RB}^{+}$) was found to have tolerogenic activity and the ability to induce regulatory $\mathrm{T}$ cells in the periphery (84). A recent study showed that plasmacytoid DCs induced the generation of $\mathrm{CD} 25^{+} \mathrm{CD}^{+}{ }^{+}$Foxp $^{+}$regulatory T cells in lymph nodes (85).

The transcriptional signature of dendritic cells has been investigated to better understand their immune phenotype. A recent study examining the role of RelB, a transcription factor that belongs to the NF-kB/Rel family, in steady-state dendritic cells demonstrated that absence of this transcription factor is associated with increased populations of not only $\mathrm{CD} 25^{+} \mathrm{CD}^{+}{ }^{+}$Foxp $^{+}{ }^{+}$regulatory $\mathrm{T}$ cells, but also IL-2-producing $\mathrm{CD} 25^{\text {low }} \mathrm{CD} 4{ }^{+} \mathrm{CD} 44^{\text {High }} \mathrm{T}$ memory type 1 (Tm1) cells (86). The transcription factor IRF4, on the other hand, has been associated with establishing an immunogenic DC phenotype by promoting Th2 differentiation via IL-10 and IL-33 expression (87), however, further studies have demonstrated that IRF4 is also involved in DC priming of peripheral Foxp $3^{+}$regulatory $\mathrm{T}$ cells (88). Another transcription factor that has been investigated is dendritic cell-specific transcript (DC-SCRIPT), which, when knocked down, promotes expression of IL-10 and decreases expression of IL-12 by DCs (89). To better understand the mechanisms of this, Søndergaard et al. demonstrated that knock down of DC-SCRIPT was associated with decreased expression of MAPK dual-specific phosphatases (DUSP), specifically DUSP4, which concomitantly enhanced ERK signaling, leading to increased IL-10 production (90).

In parallel with classic anti-inflammatory cytokines, other metabolites present in the local immune environment can promote immune tolerance. One critical pathway implicated in generating tolerogenic DCs involves the catabolism of the amino acid tryptophan. DCs can produce indoleamine 2,3 dioxygenase (IDO), the rate-limiting enzyme in the catabolic pathway for tryptophan $(91,92)$, which degrades the indole moiety of tryptophan, serotonin, and melatonin, and initiates the production of kynurenines. IDO catalyzes the local depletion of the essential amino acid tryptophan, which enhances the production of proapoptotic kynurenines that inhibit T-cell proliferation and promote T-cell apoptosis $(91,92)$.

Similar to IDO, the enzyme tryptophan-2,3-dioxygenase 2 (TDO) is an enzyme that is involved in the degradation of tryptophan and represents an alternative catabolic pathway. Previously, this enzyme was thought to be expressed only in the liver and neuron, where it is involved in regulating levels of tryptophan systemically and 5-hydroxy-tryptophan in the central nervous system, respectively (93). However, there is increasing evidence suggesting that TDO can be produced by a variety of cancers, including hepatocellular carcinoma, glioma, melanoma, and others (94). In addition, recent studies have demonstrated that certain, specialized myeloid cells can express TDO and contribute to an immunosuppressive microenvironment $(95,96)$. The exact biologic and molecular basis for such a regulatory myeloid cell subset, however, is unclear.

APC surface ligands, particularly the B7 family molecules, also play an important role in inducing $\mathrm{T}$ cell dysfunction to promote peripheral tolerance. At least five B7-family molecules have co-inhibitory function: B7-1 (CD80), B7-2 (CD86), B7-H1 (PD-L1), B7-DC (PD-L2), and B7-H4 (B7x) (97, 98). CD80 and $\mathrm{CD} 86$ are the main co-stimulators for $\mathrm{T}$ cells through binding to CD28. CD80 and CD86, however, can be co-inhibitory for effector T cells after ligation with CTLA-4. B7-H1 and B7-DC deliver a co-inhibitory signal to effector $\mathrm{T}$ cells through ligation of programmed cell death 1 (PD-1). B7-H4 binds to a putative receptor to deliver a negative signal to $\mathrm{T}$ cells. Collectively, these B7-family molecules have both co-stimulatory or co-inhibitory activities to balance immune responses $(97,98)$. In addition to being found on APCs, the B7 family ligands can also be found on peripheral tissue and tumor cells, which we discuss in further detail in the following sections. The APC surface ligands in this family and the $\mathrm{T}$ cell receptors they interact with are the main targets of the therapies whose successes have transformed our understanding of cancer medicine and brought about the Era of Checkpoint Blockade Immunotherapy. 


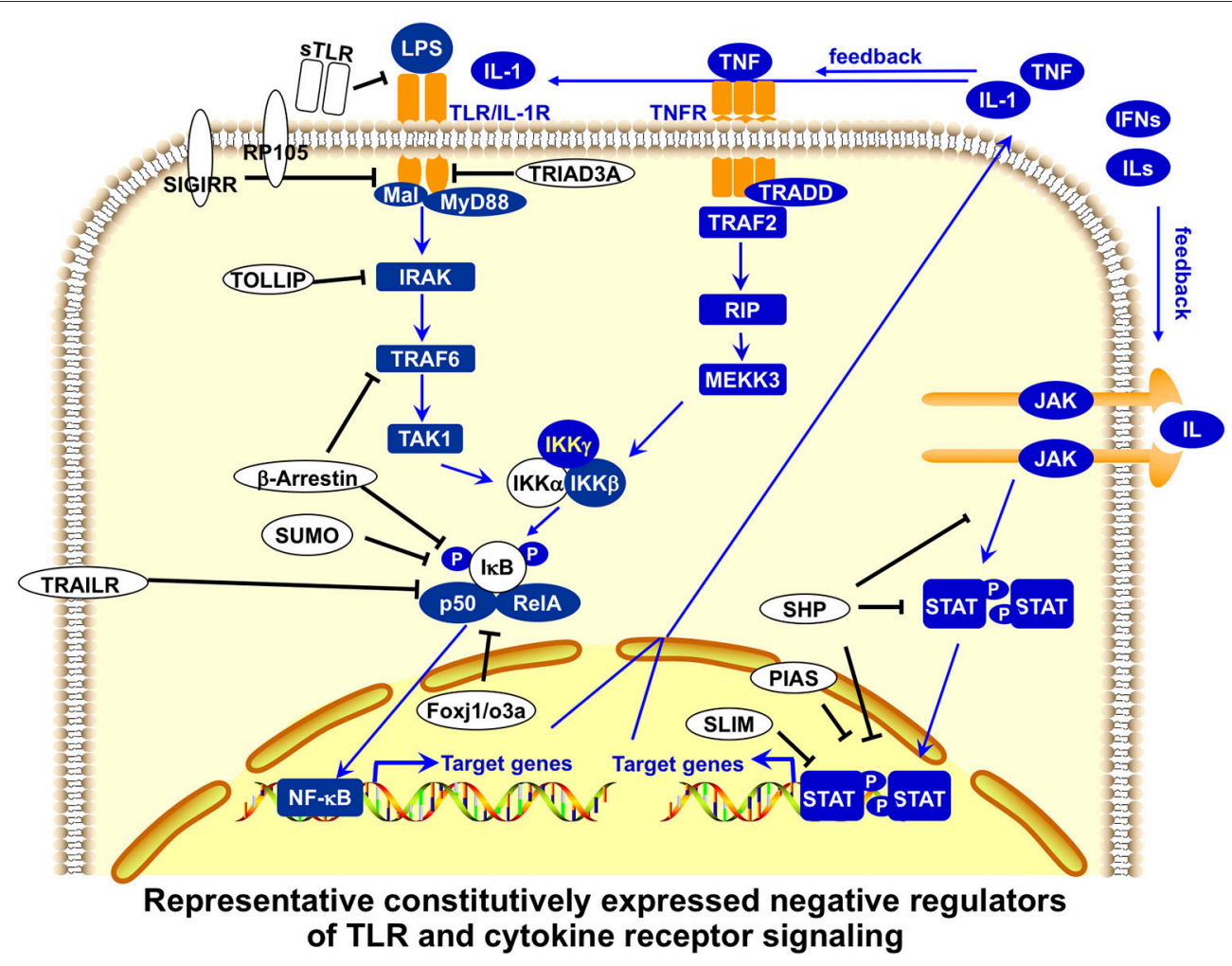

FIGURE 3 | Representative, constitutively expressed negative regulators of TLR and cytokine receptor signaling in APCs. Toll-like receptor (TLR) signaling is regulated by constitutively expressed negative regulators at multiple points. Soluble forms of Toll-like receptors (sTLR) inhibit the binding of membrane-bound TLR to microbial ligands. Membrane-bound SIGIRR (single immunoglobulin interleukin-1-related receptor) binds to TLR4 and IRAK (interleukin-1 receptor-associated kinase), and terminates the downstream TLR signaling pathways, whereas TRAIL-R (tumor-necrosis factor-related apoptosis-inducing ligand receptor) suppresses nuclear

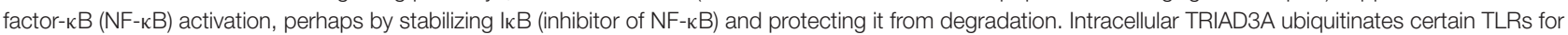
degradation. TOLLIP (Toll-interacting protein) suppresses IRAK function by inhibiting TLR signaling. NOD2 might inhibit TLR2 signaling by suppressing NF- $\kappa$ B activity. SUMO sumoylates and stabilizes the inhibitor of NF-кB. Transcription factors Foxj1 and Foxoa3 activate expression of the inhibitor of NF-кB. Cytokine receptor signaling is also regulated by constitutively expressed negative regulators at multiple points. SHP proteins dephosphorylate activated JAKs or receptors. PIAS proteins block the binding of STATs and SUMOylate STATs to inhibit their transcriptional activation, whereas STAT-interacting LIM protein (SLIM) ubiquitinates STAT1 and STAT4 for degradation. Many of these negative regulators also play important roles in regulating T-cell activation and function (65).

\section{Negative Regulation of T Cells}

The second level of regulation of peripheral tolerance directly inhibits the activation and effector function of lymphocytes such as $\mathrm{T}$ cells. As in the negative regulation of APCs, negative regulators of proinflamamtory signaling, soluble antiinflammatory factors, inhibitory surface receptors and ligands, and regulatory cell subsets play an important role in the regulation of $\mathrm{T}$ cell function (Figures 1,5). Additionally, negative regulators that control $\mathrm{T}$-cell receptor (TCR) signaling are important in the maintenance of $\mathrm{T}$ cell tolerance. In this section, we highlight some negative regulators that act directly on $\mathrm{T}$ cells to influence activation and tolerance.

Many of the negative regulators of proinflammatory TLR and cytokine signaling, and anti-inflammatory factors such as IL-10 and TGF $\beta$ described above are also important for the regulation of T-cell activation and tolerance (Tables 1, 2). T cells express TLR and cytokine receptors and are subject to the regulation of TLR and cytokine receptor signaling by the same negative regulators described above. T-cell receptor (TCR) signaling is unique to $\mathrm{T}$ cells, and activates at least three different families of transcription factors: the nuclear factor of activated $\mathrm{T}$ cells (NFAT) family, the activating protein (AP)-1 family, and the nuclear factor NF- $\mathrm{B}$ family $(99,100)$. The negative regulators of TCR signaling include NFATp, NFAT4, MKP, Cbl, Tob, MKP, Foxj1, Foxo3a, Foxp3, Calcipressins, etc. The detailed roles of many of these regulators of TCR signaling (101), TLR signaling (65), and cytokine receptor signaling (102) in T cells have been recently reviewed.

A regulatory cell subset of $\mathrm{T}$ cells, appropriately named regulatory $\mathrm{T}$ cells (Tregs), are also important players in the maintenance of peripheral tolerance Figure 5. Forkhead box P3 (Foxp3), a member of the forkhead transcriptional factor family, is a transcription factor that plays an essential role in the development and function of $\mathrm{CD} 4{ }^{+} \mathrm{CD} 25^{+}$regulatory $\mathrm{T}$ cells $\left(\mathrm{T}_{\text {reg }}\right)(103,104)$. Foxp $3^{+} \mathrm{CD} 25^{+} \mathrm{CD} 4^{+} \mathrm{T}_{\text {reg }}$ cells play a role in suppressing immune responses in a trans-acting way, mainly via the production of anti-inflammatory factors such as IL-10 and TGF- $\beta$. Mutations in the gene encoding Foxp 3 were identified as the cause of the fatal human autoimmune disorder "immune dysregulation, polyendocrinopathy, enteropathy, X-linked” 


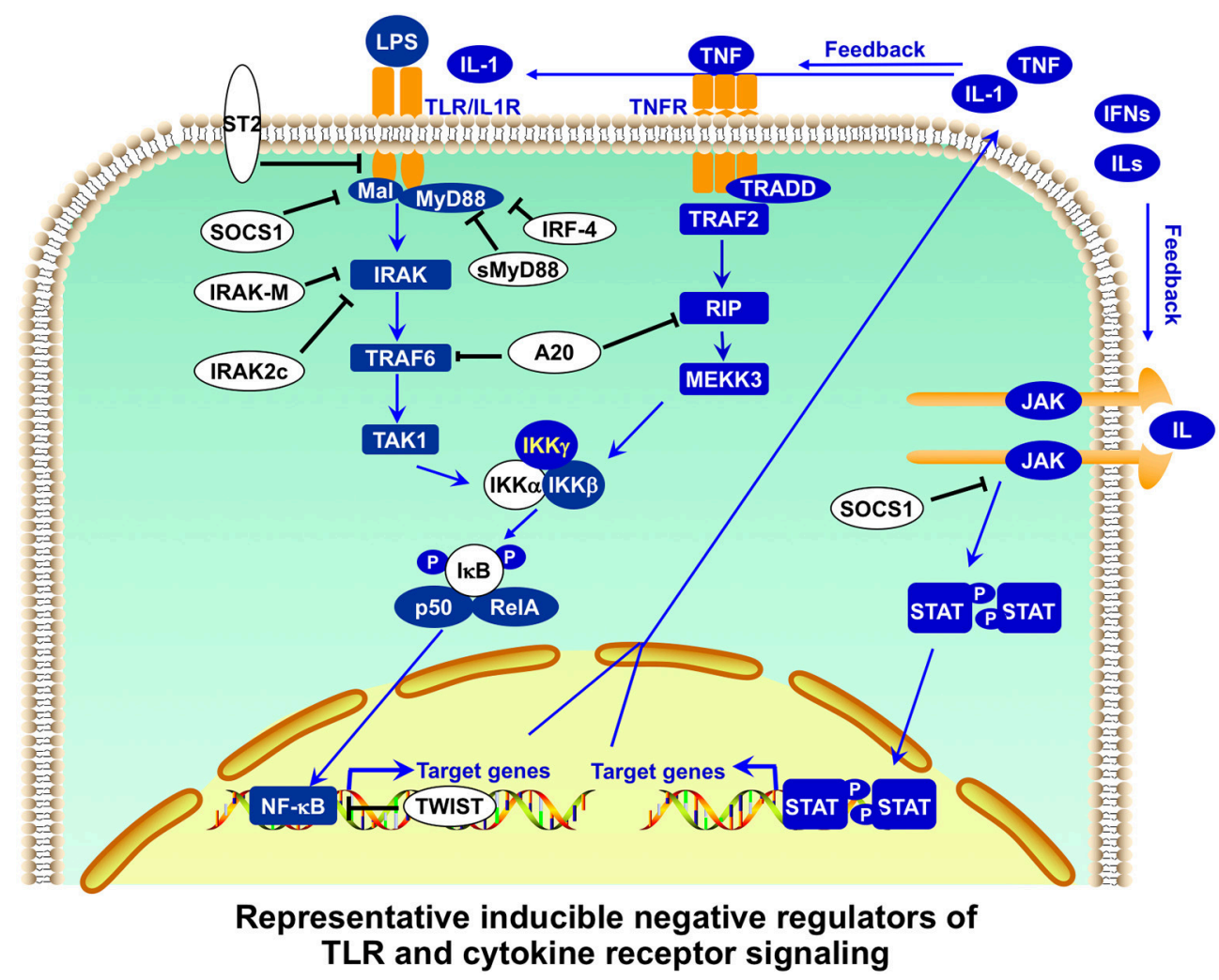

FIGURE 4 | Representative inducible negative regulators of TLR and cytokine receptor signaling in APCs. Toll-like receptor (TLR) signaling is further regulated by inducible negative regulators in a feedback manner. Membrane-bound ST2 interacts with MyD88 and Mal, and sequesters MyD88-dependent nuclear factor- $\mathrm{B}$ (NF-кB) from activation. MyD88s (the short form of MyD88) antagonizes MyD88 functions. Intracellular IRAKM (interleukin-1 (IL-1) receptor-associated kinase M) inhibits the dissociation of IRAK-IRAK4 and subsequent formation of IRAK-TRAF6. SOCS1 promotes the ubiquitination of Mal for degradation. A20 has dual functions of ubiquitination and deubiquitination of RIP and TRAF6 (tumor-necrosis factor-receptor-associated factor 6) for their degradation, inhibiting both TLR and TNFR signaling. Transcription repressor Twist-2 inhibits the transcription of NF-kB-targeted genes. Cytokine receptor signaling is also regulated by inducible negative regulators. SOCS1, in addition to regulating TLR signaling, inhibits JAK activity as a pseudosubstrate or promotes the ubiquitination and subsequent degradation of JAK. Many of these negative regulators also play important roles in regulating T-cell activation and function (65).

(IPEX) (21, 22, 105). Foxp3-deficient mice or spontaneous Foxp3 mutant scurfy mice also exhibit severe autoimmune pathologies including dermatitis, lymphoproliferation, and lymphocytic infiltration of multiple organs $(23,24)$. Foxp 3 is highly expressed in $\mathrm{CD} 25^{+} \mathrm{CD} 4^{+} \mathrm{T}_{\text {reg }}$ cells, although low levels of Foxp3 are also expressed in naive and activated $\mathrm{CD} 25^{-} \mathrm{CD} 4^{+} \mathrm{T}$ cells (106). Several lines of evidence indicate that $\mathrm{CD} 4^{+} \mathrm{CD} 25^{+} \mathrm{T}_{\text {reg }}$ cell development is critically dependent on Foxp3 expression (103, 104): Foxp3-deficient bone marrow cannot give rise to $\mathrm{CD} 4{ }^{+} \mathrm{CD} 25^{+} \mathrm{T}_{\text {reg }}$ cells in chimeric wild-type mice; Foxp3 transgene overexpression in mice resulting in an increase in the $\mathrm{CD} 4{ }^{+} \mathrm{CD} 25^{+} \mathrm{T}_{\text {reg }}$ cell subset and acquisition of suppressive properties by $\mathrm{CD} 4{ }^{+} \mathrm{CD} 25^{-}$and $\mathrm{CD} 8^{+} \mathrm{T}$ cells; the acquisition of regulatory properties by $\mathrm{CD} 4{ }^{+} \mathrm{CD} 25^{-} \mathrm{T}$ cells after retroviral transduction with Foxp3; and the association of induced Foxp3 expression with acquired regulatory functions of non-regulatory T cells in both humans and mice.

Like other forkhead transcriptional factors (107), Foxp3 binds DNA and acts as a transcriptional activator or repressor. Foxp3 may function as a transcriptional repressor of proinflammatory cytokine genes, because Foxp3 can bind to consensus forkhead binding domains adjacent to NFAT transcription factor binding sites in the promoters of several cytokine genes, such as IL-2, IL-4, and TNF (108). Foxp3-targeted genes and transcriptional regulation, however, are still not defined. Collectively, Foxp3 functions as a negative regulator of immune responses by repressing the production of proinflammatory cytokines in a variety of cell types, including $\mathrm{CD} 25^{+} \mathrm{CD} 4^{+} \mathrm{T}_{\text {reg }}$ cells, which, together with other regulatory cells $(75,109)$, provide one of many non-redundant regulatory mechanisms for maintenance of peripheral tolerance (Figure 5).

There additionally exist populations of regulatory $\mathrm{CD}^{+}{ }^{+} \mathrm{T}$ cells that lack expression of Foxp3, such as $\operatorname{Tr} 1$ cells that are uniquely identified as expressing both cell-surface markers CD49 and LAG-3, and produce high levels of IL-10 and TGF- $\beta$ (110, 111). In addition to producing anti-inflammatory cytokines, Tr1 cells are capable directly lysing myeloid APCs by secreting granzymes and perforins via a mechanism dependent on HLA class 1 recognition, CD54/LFA-1 adhesion, killer cell Ig-like receptors (KIRs), CD2, and CD226 on Tr1 cells (112). Recent studies have elucidated the differentiation pathway for Tr1 cellsIRF1 and BATF have been implicated as pioneer factors for 


\section{Peripheral tolerance is maintained by at least four non-redundant regulatory mechanisms}

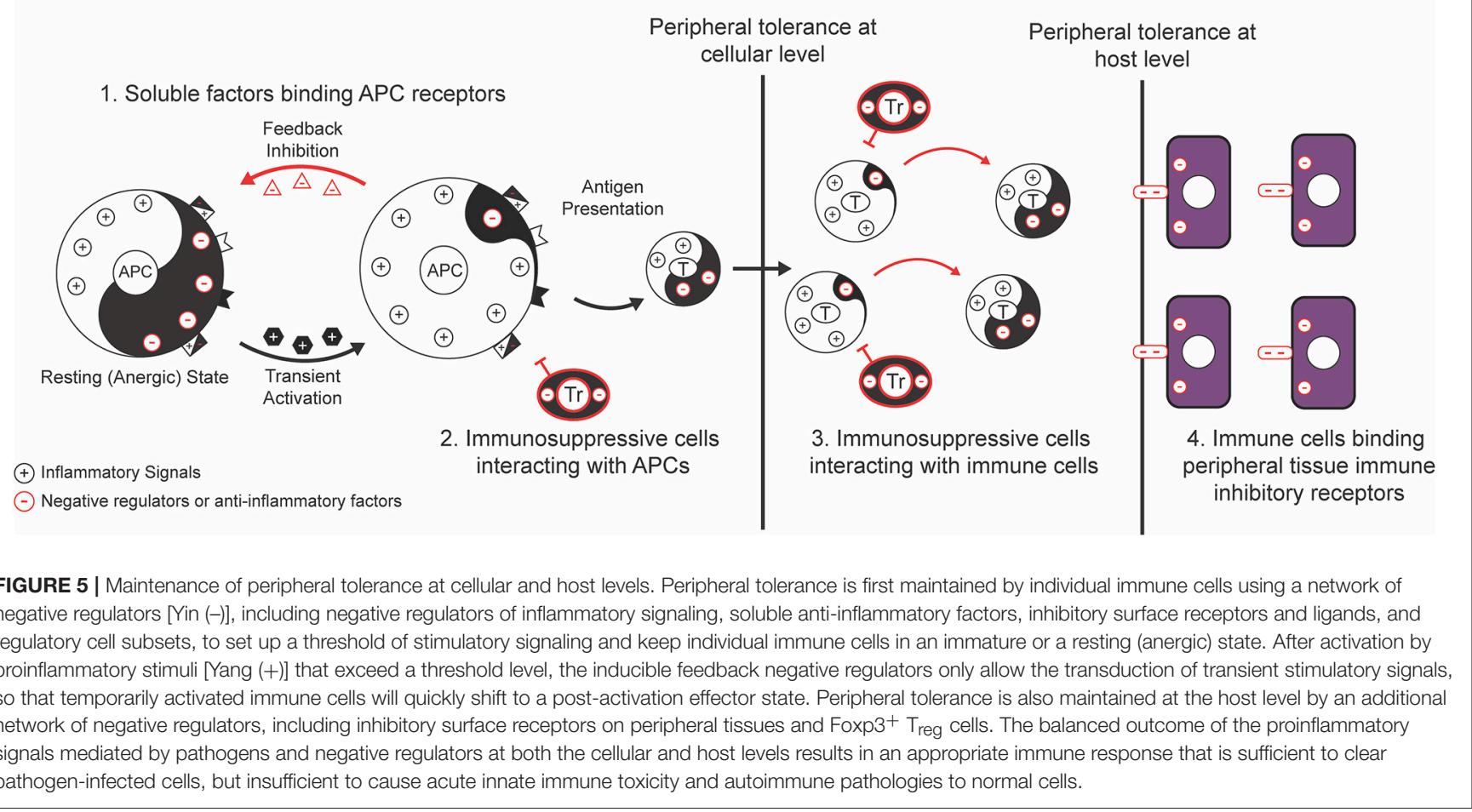

Tr1 cell development in response to IL-27 signaling (113). Additionally, IL-2 inducible T cell kinase (ITK), serves an important role as ITK deficiency lead to diminished expression of AHR, cMAF, and IRF4, transcription factors involved in Tr1 cell development (114); IRF4 in particular can modulate expression of Blimp-1, and together, induce IL-10 production (115).

In addition to regulatory $\mathrm{CD} 4^{+} \mathrm{T}$ cells, recent studies have identified regulatory $\mathrm{CD}^{+} \mathrm{T}$ cells that suppress naïve $\mathrm{T}$ cell proliferation and are vital for maintaining self-tolerance (116120). Compared to other $\mathrm{CD}^{+} \mathrm{T}$ cells, regulatory $\mathrm{CD} 8^{+} \mathrm{T}$ cells express higher levels of markers such as CTLA-4 and ICOS, and constitutively express CD25, increasing their sensitivity to IL-2 (116). When examining the transcriptional profile, regulatory $\mathrm{CD}^{+} \mathrm{T}$ cells more closely resemble regulatory $\mathrm{CD} 4^{+}$ $\mathrm{T}$ cells compared to other, canonical $\mathrm{CD}^{+} \mathrm{T}$ cells (121). One pathway implicated in the differentiation and function of $\mathrm{CD}^{+}$Foxp $^{+} \mathrm{T}$ cells is TNF/TNFR2, and TNFR2 may be used as a marker to identify these cells $(122,123)$. A key mechanism by which regulatory $\mathrm{CD}^{+} \mathrm{T}$ cells can mediate naïve $\mathrm{CD}^{+} \mathrm{T}$ cell proliferation is via TGF-beta and IFNgamma secretion (124); TGF-beta is also partially involved in promoting regulatory $\mathrm{CD} 8^{+} \mathrm{T}$ cell differentiation via $\mathrm{p} 38 \mathrm{MAPK}$ signaling (125). A different mechanism to mitigate $\mathrm{CD} 4^{+} \mathrm{T}$ cell proliferation utilized by subsets of regulatory $\mathrm{CD} 8^{+} \mathrm{T}$ cells that express high levels of CD11c employs the Fas-FasL pathway in an antigen-independent manner to mediate direct cytotoxicity (126). It is becoming more appreciated that both $\mathrm{CD}^{+}$and $\mathrm{CD} 8^{+}$regulatory $\mathrm{T}$ cells strongly contribute to maintaining immune tolerance, and may serve to increase an individual's immune threshold.

A regulatory subset of $\mathrm{B}$ cells, termed regulatory $\mathrm{B}$ (Breg) cells have been gaining recognition as playing in important role in suppressing the immune response by producing cytokines such as IL-10, IL-35, and TGF- $\beta$ (127-129). Breg cells were initially postulated to exist and exert an immunosuppressive effect upon the observation that B cell deficient mice had more severe disease and delayed recovery in a murine model of experimental autoimmune encephalomyelitis (130). There exist multiple subsets of Breg cells, including B10 cells, regulatory plasma cells, Marginal Zone (MZ) B cells, and many others, and the majority of these subsets can be identified by high surface expression of CD1d (131). CD1d belongs to the CD1 family of cell surface receptors that resemble MHC I, collectively bind lipid molecules by their hydrophobic carbon chain, and presents these antigens to invariant natural killer T (iNKT) cells $(132,133)$. One such molecule that is bound by CD1d on B cells is alphagalactosylceramide, a potent iNKT cell agonist that performs a vital role in regulating immune tolerance $(133,134)$. Mechanistic studies have revealed that lipid presentation on CD1d by Breg cells drives differentiation of IFN-gamma ${ }^{+}$iNKT cells, which successively can inhibit Th1 and Th17 responses (135).

One of the key cytokines implicated in driving Breg cell function is IL-10, and this large subset of IL-10-producing Breg cells is known collectively as B10 cells, the most extensively characterized of Breg cells $(136,137)$. Yanaba et al. utilized high cell surface expression of CD1d and CD5 to identify B10 cells, 
however, there is no consensus set of cell surface markers to uniformly define this subset of Breg cells $(138,139)$. While the precise molecular mechanism inducing B10 cell differentiation is unclear, interactions with $\mathrm{T}$ cells do not seem to be a necessary prerequisite, as nude mice lacking $\mathrm{T}$ cells can still possess $\mathrm{B} 10$ cells (139). B10 cells have been shown to have the ability to regulate antigen-specific immune responses in the presence of IL21 and CD40-based interactions with T cells (140). In a murine model for collagen-induced arthritis, B10 cells suppressed Th1 and Th17 differentiation in an IL-10-dependent fashion as mice with IL-10 $10^{-/}$B cells developed more severe disease, increased populations of Th1 and Th17 cells, and decreased populations of $\operatorname{Tr} 1$ cells compared to mice with wild-type B cells (141). While B10 cells secrete IL-10 to dampen the immune response, following il10 transcription, the genes encoding transcription factors Blimp-1 and IRF4 are transcribed, indicating an ability to further differentiate into plasma cells, possibly to promote clearance of antigens via antibody-mediated processes (142). In humans, there exists a rare population of $\mathrm{CD} 19^{+} \mathrm{CD} 24^{\text {hi }} \mathrm{CD} 38^{\text {hi }}$ $\mathrm{B}$ cells that that serve to regulate the immune response partially via IL-10 (143). Concordantly, in patients with rheumatoid arthritis, $\mathrm{CD} 19^{+} \mathrm{CD} 24^{\mathrm{hi}} \mathrm{CD} 38^{\mathrm{hi}} \mathrm{B}$ cells are not only presents in reduced numbers, but also have a decreased ability to suppress naïve T cell differentiation into Th1 and Th17 cells and promote differentiation into $\mathrm{T}$ regulatory cells (144).

In addition to IL-10, IL-35, which amongst $B$ cells is produced primarily by $\mathrm{CD} 138^{+}$plasma cells, has been increasing investigated in its immune regulatory function, which parallels those of IL-10 $(129,145,146)$. IL-35 belongs to the IL-12 family of cytokines and is comprised of p35, the IL-12-alpha chain, and Epstein-Barr virus-induced gene 3 (Ebi3) (147). IL-35 itself is partially governed by a positive feedback loop as IL-35 signaling enhances binding of STAT1 to p35 and Ebi3 promotors in a subset of Foxp3 ${ }^{-}$regulatory T cells known as "iTR35" cells, and successively increases expression and secretion of these proteins (148). Decreased expression of IL-35 has been reported in multiple autoimmune disease states, including inflammatory bowel disease, Sjogren syndrome, type 1 diabetes, and others (148-150). Importantly, treatment of mice with IL-35 strongly promoted expansion of IL-10-producing Breg cells and decreased IL-17 expression $(151,152)$. Furthermore, IL-35 has been shown to modulate activation and antigen presenting capabilities of $\mathrm{B}$ cells, as mice with $\mathrm{p} 35^{-/-} \mathrm{B}$ cells expressed higher levels of activation markers such as CD44 and CD69, and molecules involved in antigen presentation such as MHC-II, CD80, and CD86 (129). While further studies detailing the molecular mechanisms governing Breg cell interactions with $\mathrm{T}$ cells and other immune cells, it is becoming increasing clear that Breg cells serve an important role in regulating the immune response.

\section{Negative Regulation in Peripheral Tissues}

The third level of regulation of peripheral tolerance occurs in peripheral, non-lymphoid tissues. Various regulatory mechanisms (Figure 1) are used by peripheral tissues to protect themselves against self-reactive $\mathrm{T}$ cells. The defense mechanisms of peripheral tissues are important for the maintenance of peripheral tolerance at the host level, when other regulatory mechanisms are unable to restrict the activation of pathogenic self-reactive T cells at the cellular level.

The negative regulators of proinflammatory signaling are also expressed in peripheral tissues and play a role in maintaining peripheral tolerance at the host level. For example, it was reported that diabetes-prone NOD mice harboring beta-cells expressing a SOCS1 transgene had a markedly reduced incidence of diabetes, and the disease protection was correlated with enhanced suppression of STAT1 phosphorylation in SOCS1expressing beta-cells (153).

Peripheral tolerance also utilizes the Fas ligand (FasL) response pathway to regulate apoptosis of self-reactive $\mathrm{T}$ cells. FasL (CD95L, Apo-1L, CD178), a member of TNF family, binds to its cognate surface receptor Fas (CD95, Apo-1) and triggers the extrinsic apoptotic pathway, leading to the death of target cells (154). The Fas/FasL apoptotic pathway is highly regulated, and its abnormal regulation has been associated with autoimmunity and cancer. Although predominantly expressed on activated T cells and NK cells, FasL is also expressed on non-hematopoietic cells such as brain, lung, and immunologically privileged sites to protect these tissues and organs from pathogenic self-reactive $\mathrm{T}$ cells (155).

As seen at the levels of APCs and lymphocytes, B7 family members also play a critical role in maintaining self-tolerance at the level of peripheral tissues. PD-L1, B7-H3, and B7$\mathrm{H} 4$, are important for protecting peripheral tissues against pathogenic self-reactive $\mathrm{T}$ cells $(98,156)$. A hint of the protective role of $\mathrm{B} 7$ molecules comes from the observation that inhibitory B7 members such as PD-L1 and B7-H4 are also expressed on non-lymphoid tissues such as heart, muscle, lung, kidney, liver, and various cancer cells. Recently, Keir et al. experimentally demonstrated that PD-L1 expressed on pancreatic islets prevented diabetes by providing an inhibitory signal to infiltrating self-reactive $\mathrm{CD}^{+} \mathrm{T}$ cells (156). Chronic stimulation of $\mathrm{T}$ cells by these inhibitory $\mathrm{B} 7$ family ligands can lead to a semi-permanent downregulation of $\mathrm{T}$ cell function. Tumors exploit this system, overexpressing these ligands to create a tolerogenic microenvironment that fosters tumorigenesis.

The negative regulatory mechanisms employed by peripheral tissues serve as a last line of defense against the development of autoimmunity. Taken together with the negative regulatory mechanisms employed by APCs, T cells, and B cells, this coordinated system maintains a heightened threshold for immune activation. Therefore, the ability of cancer cells, which originate from normal tissue, to utilize and upregulate these same mechanisms creates an critical barrier to generating an effective anti-tumor immune response.

\section{T CELL EXHAUSTION IN CANCER}

While peripheral tolerance acts to delete antigen specific T cells as a natural means of protection, $\mathrm{T}$ cell exhaustion, described more than a decade ago, is a state of $\mathrm{T}$ cell differentiation that becomes evident during persistent $\mathrm{T}$ cell stimulation. $\mathrm{T}$ cell exhaustion has been described in chronic viral, bacterial, and parasitic infections and in cancer in various animal models 
and humans, and the functional depiction continues to become clearer. T cell exhaustion can be best understood by considering the extrinsic and cell-intrinsic pathways responsible for negative regulation of $\mathrm{T}$ cell function.

\section{T Cell Response to Antigen and Loss of Effector Function}

Upon acute antigen exposure, naïve $\mathrm{CD} 8^{+} \mathrm{T}$ cells expand and differentiate into cytotoxic effector cells to control and clear the antigen. Further differentiation results in either functional $\mathrm{T}$ cell memory or T cell dysfunction as in self-tolerance or exhaustion. The fate of the naïve $T$ cell is dependent on the context of antigen stimulation and defined by unique genetic signatures that determine the functional and phenotypic properties of each $\mathrm{T}$ cell differentiation state. $(157,158)$. When self-reactive $\mathrm{CD}^{+} \mathrm{T}$ cells come in contact with self-antigen in the tolerogenic setting of the peripheral tissues, they adopt a state of unresponsiveness. Tolerant $\mathrm{T}$ cells can become activated by various conditions that promote $\mathrm{T}$ cell proliferation (including cytokines IL-2 and IL-15, and lymphopenia), but this rescue of $\mathrm{T}$ cell function is transient, and self-reactive $\mathrm{T}$ cells are re-tolerized in the absence of proliferative stimulation.

Another state of $\mathrm{T}$ cell dysfunction is $\mathrm{T}$ cell exhaustion. Rather than a state of irreversible, terminal differentiation or functional unresponsiveness, $\mathrm{T}$ cell exhaustion is characterized by an adaptive state of hyporesponsiveness. By maintaining a low level of cytotoxic function, exhausted $\mathrm{T}$ cells are able to help control a chronic threat without producing a full blown immune response that could potentially induce fatal disease in the host (159). Properties of T cell exhaustion were first identified in lymphocytic choriomeningitis virus (LCMV) infection, where chronic infection led to persistent antigen presentation (160). In chronic LCMV infection, virus-specific $\mathrm{CD} 8^{+} \mathrm{T}$ cells that do not produce typical cytotoxic molecules were identified, suggesting that highly cytotoxic $\mathrm{T}$ cells generated during initial responses are lost upon prolonged antigen presentation. Soon after, studies described that during exhaustion, loss of function occurs in a hierarchical manner, where IL-2 production and proliferative capacity are lost first, followed by loss of tumor necrosis factor (TNF) production at intermediate stages of dysfunction. Finally, severe exhaustion can lead to complete loss of the ability to produce IFN $\gamma$, and the final stage of exhaustion is followed by physical deletion of antigen-specific $\mathrm{T}$ cells.

A key property of memory $\mathrm{CD} 8^{+} \mathrm{T}$ cells is the ability to survive without antigen stimulation via interleukin (IL)-7 and IL-15 to mediate self-renewal. This feature is lost upon exhaustion, as they have decreased expression of CD122 (the B-chain of the IL-2 and IL-15 receptor) and CD127 (the IL-7 receptor a-chain). As a result, these $\mathrm{T}$ cells switch to using their cognate antigen and epitope-specific TCR signals for long-term maintenance. Studies in mice have revealed that when exhausted $\mathrm{T}$ cells are adoptively transferred into antigen-free recipients, there is a disappearance of exhausted cells but also minimal recovery of memory $\mathrm{CD} 8^{+} \mathrm{T}$ cells. This verified that once $\mathrm{T}$ cells are committed to exhaustion, antigen removal does not restart the memory $\mathrm{T}$ cell differentiation process (161). Epigenetic studies have revealed that exhausted $\mathrm{CD}^{+} \mathrm{T}$ cells have an accessible chromatin landscape, and corresponding program of genes, that is distinct from memory T cells (162). Specifically, a seminal study by Sen et al. identified a region in the $P d c d 1$ gene locus demonstrated significant chromatin accessibility only in exhausted $\mathrm{CD}^{+} \mathrm{T}$ cells (162). Mechanistically, de novo DNA methylation is critical to differentiation into an exhausted subtype, and these DNA methylation programs can be acquired by tumor-infiltrating $\mathrm{CD} 8^{+} \mathrm{T}$ cells (163). Importantly, administration of DNA demethylating agents prior to CBI may avoid $\mathrm{T}$ cell exhaustion in tumorinfiltrating $\mathrm{CD}^{+} \mathrm{T}$ cells (163). Exhausted $\mathrm{T}$ cells, however, can be rescued, and this principle has had significant clinical implications on cancer immunotherapy, which we discuss later in this review.

\section{Negative Regulatory Pathways Leading to Exhaustion}

Functional, phenotypic, and molecular analyses have revealed that despite overlapping traits, many of the states labeled in the literature as "anergy" are regulated and maintained by distinct factors, and require different strategies to restore cell function. While there are various states of $\mathrm{T}$ cell dysfunction, $\mathrm{T}$ cell exhaustion is a progressive, long-term process which involves various negative regulatory mechanisms. These mechanisms can be grouped into three main categories: (1) cell surface inhibitory receptors, (2) soluble factors, and (3) immunoregulatory cell types. These specific negative regulatory mechanisms distinguish exhausted $\mathrm{T}$ cells from anergic, tolerant, or ignorant $\mathrm{T}$ cells.

Inhibitory receptors on the surface of $\mathrm{T}$ cells play vital roles in many aspects of self-tolerance and prevention of autoimmunity. While $\mathrm{T}$ cells transiently express inhibitory receptors upon activation, prolonged and/or high expression of multiple inhibitory receptors is a defining feature of exhaustion (164).

PD-1 is expressed on antigen-activated T cells and upregulated in $\mathrm{T}$ cell exhaustion (165). In the presence of its ligands, PD-L1 and PD-L2, on the surface of APCs and normal and cancerous peripheral tissue, PD-1 functions to suppress T cell inflammatory activity. Binding of either of these ligands to PD-1 results in the recruitment of phosphatases SHP-1 and SHP-2 to the phosphorylated cytoplasmic ITSM domain of the receptor. These phosphatases then counteract kinases important for signal transduction downstream of TCR, CD28, and other costimulatory receptors. By inhibiting activation of the PI3K and Akt pathways among others, PD-1 signaling results in decreased proliferation, IL-2 production, protein synthesis, and survival of T cells (166). PD-L1 is expressed on various cells throughout the body, protecting tissues from immune-mediated damage (156). Like CTLA-4, PD-1, as well as PD-L1, are highly expressed on $\mathrm{T}_{\text {regs }}$, and activation of the PD-1/PD-L pathway favors the differentiation of naive $\mathrm{T}$ cells into Tregs to create a more immune-suppressive environment.

In addition to PD-1, various other inhibitory surface receptors are important in regulatory $\mathrm{T}$ cell exhaustion. As discussed above, CTLA-4 shares ligands, B7-1 (CD80) and B7-2 (CD86), with $\mathrm{CD} 28$, a co-stimulatory receptor required for the second 
signal in T cell activation. CTLA-4 binds B7-1 (CD80) and B72 (CD86) with 10-20 times greater affinity than CD28, resulting in competitive inhibition of the co-stimulatory receptor. CTLA-4 binding also leads to endocytosis of B7 molecules, decreasing the availability of these ligands on APCs, peripheral tissue, and tumor cells for T cell co-stimulation via CD28.

CTLA-4 is an important negative regulator at the level of lymphocytes, and functions to modulate the extent of early $\mathrm{T}$ cell activation via two main mechanisms. First, upon activation, T cells start expressing CTLA-4, which blocks further activation and blunts the immune response. As a target gene of FOXP3, the transcription factor whose presence defines the $\mathrm{T}_{\text {reg }}$ cell lineage, CTLA- 4 is also expressed constitutively in high levels on $\mathrm{T}_{\text {regs }}$, enabling them to prevent the activation of other $\mathrm{T}$ cells $(24,167,168)$. CTLA-4 acts on two major subsets of $\mathrm{CD}^{+}{ }^{+} \mathrm{T}$ cells, dampening helper $\mathrm{T}$ cell activity while boosting the immunosuppressive functions of $\mathrm{T}_{\text {regs }}$. CTLA- 4 also has some direct effect on $\mathrm{CD}^{+} \mathrm{T}$ cells, negatively regulating their proliferation and activation (169).

Two additional inhibitory receptors are also important in $\mathrm{T}$ cell exhaustion: lymphocyte activation gene-3 (LAG3) and T cell immunogloblulin and mucin domain 3 (TIM3). LAG3 was discovered over 25 years ago as a receptor that is upregulated on activated $\mathrm{CD}^{+}{ }^{+}$and $\mathrm{CD} 8^{+} \mathrm{T}$ cells and also natural killer (NK) cells, and are detectable on a $\mathrm{T}$ cell as early as $24 \mathrm{~h}$ post activation (170). LAG3 structurally resembles the $\mathrm{CD} 4^{+}$receptor and binds to MHC Class II, but its functional impact on CD8 and NK cells, which only interact with MHCI, implies that LAG3 also has alternative ligands. Liver sinusoidal endothelial cell lectin (LSECtin) and Galectin-3 have been speculated to be additional ligands for LAG3 and have been found to be expressed on cancer cells to inhibit IFN $\gamma$ secretion by $\mathrm{CD}^{+} \mathrm{T}$ cells (171). Recently, fibrinogen-like protein 1 (FGL1) has been identified as a high-affinity LAG3 ligand that can inhibit antigenspecific $\mathrm{T}$ cell responses and is upregulated in various cancers such as lung adenocarcinoma, prostate cancer, and breast cancer (172).Moreover, LAG3 has also been found on $\mathrm{T}_{\text {reg }}$ cells, and blocking LAG3 diminishes suppressor function (173). TIM3 has been shown to play an inhibitory role in $\mathrm{T}$ cell immune responses. TIM3 is expressed on $\mathrm{CD}^{+}$and $\mathrm{CD}^{+} \mathrm{T}$ cells and is correlated with reduced amounts of cytokine production and also decreased proliferation, suggesting that they play a role in exhausted $\mathrm{T}$ cells. $\mathrm{T}$ cells isolated from chronic viral infections and various human cancer samples include a fraction of antigen-specific, nonfunctional CD8 ${ }^{+}$T cells that coexpress LAG3/TIM3 and PD1 (160). In these models, blockade of both receptors resulted in an improved and synergistic antiviral and anti-tumor immune response compared to singular blockade $(174,175)$.

\section{Transcriptional Definitions of Exhaustion}

Though exhausted cells share similar phenotypes, different stimuli or stimuli from different species may generate different molecular and transcriptional profiles that further distinguish them. Genomic approaches can provide a more detailed landscape of exhausted $\mathrm{T}$ cells to provide us a fuller understanding. For example, global transcriptional profiling has shown that exhausted $\mathrm{CD}^{+} \mathrm{T}$ cells are distinct from effector and memory $\mathrm{T}$ cells in terms of TCR and cytokine signaling pathways, migratory potential, chemokine expression, and metabolism (176). Genomic profiling of exhausted cells is important as it can potentially determine whether exhaustion is a fixed lineage or if plasticity exists for them to become fully functional effector or memory.

Several transcriptional pathways have already been identified for T cell exhaustion. B lymphocyte-induced maturation protein1 (Blimp-1). Blimp-1 is a transcriptional repressor and is a master regulator of terminal B cell differentiation (177). Kallies et al. however, has recently reported that Blimp-1, found on $\mathrm{CD}^{+}$and $\mathrm{CD}^{+} \mathrm{T}$ cells, is also a negative regulator of $\mathrm{T}$ cell differentiation and function. Blimp-1-deficient mice die during late gestation, and $R a g 1^{-/-}$mice reconstituted with fetal liver stem cells from Blimp-1-deficient mice show severe inflammation and multiorgan autoimmune disease. Moreover, Blimp-1 is expressed significantly higher in exhausted T cells relative to effector $\mathrm{T}$ cells, and is associated with the upregulation of many inhibitory receptors, including PD-1, LAG-3, CD160, and CD244. Ablation of Blimp-1 reverses expression of these receptors and restores memory differentiation, suggesting that lesser activity of Blimp-1 promotes formation of memory cells, intermediate amounts promote terminal differentiation of effector activity, and higher amounts generate exhaustion (178). Moreover, another transcription factor, T-bet, has a parallel role to Blimp-1 in mediating terminal differentiation of $\mathrm{CD}^{+} \mathrm{T}$ cells after clearance of antigen. T-bet promotes sustained responses during chronic viral infection and represses transcription of inhibitory receptors. Thus, Blimp-1 and T-bet represent the main transcriptional regulation nodes involved in the exhaustion of $\mathrm{CD}^{+} \mathrm{T}$ cells.

T-bet has also been shown to have a cooperative relationship with another transcription factor, Eomesodermin (Eomes). During early stages of $\mathrm{CD}^{+} \mathrm{T}$ cell activation, T-bet and Eomes cooperate to bring out cytotoxic function by inducing expression of perforin and granzymes (179). In addition, Eomes has been largely implicated in driving memory differentiation, mainly through promoting IL-15 signaling (180). While there is expressional overlap between the two, their functional roles are not necessarily reciprocal. T-bet represses expression of inhibitory receptors by direct binding to the promoter region of PD-1, while Eomes is associated with expression of numerous inhibitory receptors. Lastly, $\mathrm{T}$ cells with high levels of Eomes and PD-1 exhibited higher Blimp-1, inhibitory receptors, and are associated with a severe state of exhaustion (181). Importantly the threshold model proposed here relates primarily to the initial activation of endogenous antigen specific immune responses. After the threshold is crossed and adaptive immune responses engage a pathogen then a natural and physiologic contraction phase eventually occurs in attempt to return back to homeostasis or new baseline. This contraction phase occurs irrespective of whether a pathogen or tumor is successful eradicated or not and may involve memory formation in both cases or T-cell exhaustion in the later. Eomes plays a key role during this contraction phase and is thus involved in both memory formation and T-cell exhaustion. Indeed, negative regulators such as Eomes and even PD-1 
have a physiologic role as negative regulation is critical for maintaining homeostasis as well as memory formation during an immune response.

Transcriptional profiling also indicates that the nuclear factor of activated $\mathrm{T}$ cells (NFAT) transcription factor is highly expressed in exhausted CD8 ${ }^{+} \mathrm{T}$ cells. The NFAT family, NFAT1, NFAT2, and NFAT4, are transcription factors that promote expression of a panel of genes required for $\mathrm{T}$ cell activation and induction of numerous effector cytokines. However, recent studies have shown that they have an additional role that serves to limit the immune response. The duality of NFAT function allows these transcription factors to participate in multiple programs regulating different cell types in different signaling contexts. Importantly, the link between NFAT and T cell tolerance and anergy makes it a favorable target for cancer. Lower NFAT function and dysregulation is associated with poor cytokine production. In addition, NFAT can also regulate PD-1 expression after in vitro activation of T cells, but the link between nuclear translocation of NFAT and PD-1 expression has yet to be determined.

\section{OVERCOMING TUMOR-INDUCED T CELL DYSFUNCTION}

\section{Tumors Hijack Host Negative Regulatory Mechanisms}

In addition to the barrier of peripheral tolerance at the host level, tumors develop strategies to hijack the host's negative regulatory mechanisms in order to sabotage antitumor immunity, raising the threshold for anti-cancer immunity. Tumors can produce soluble anti-inflammatory factors such as IL-10, TGF $\beta$, and others $(182,183)$, and express inhibitory surface receptors such as B7-H4, PD-L1, and FasL (184, 185). Cancer-associated viruses such as human papillomavirus (HPV) can interrupt immune responses by up-regulating the PI3-K pathway and down-regulating MAPK pathways (186). The enhanced expression of various natural negative regulators by tumor cells establishes an immune-suppressive stromal microenvironment (187), further dampening antitumor responses. In addition, Foxp $3^{+} \mathrm{T}_{\text {reg }}$ cells are attracted to tumors, where they inhibit the function of infiltrating immune cells (184).

\section{Inhibiting Negative Regulators to Enhance Anti-tumor Immunity}

Inhibition of negative regulators that are critical for maintaining peripheral tolerance may overcome both peripheral tolerance at the host level and tumor-mediated immunosuppression, since tumors do not "invent" unique immunosuppression mechanisms, but utilize and hijack the host's natural negative regulatory mechanisms, likely via mutations and selective pressure (188). By inhibiting a key negative regulator, a patient's immune threshold can be effectively lowered, decreasing the magnitude of proinflammatory stimulation required to induce an immune response.

\section{Checkpoint Blockade Immunotherapy}

Checkpoint blockade immunotherapy (CBI) is one of the most promising examples of the application of this principle in the treatment of cancer. The term "immune checkpoint" is occasionally used as an umbrella term to refer to any of the immune-inhibitory pathways. To maintain consistency with the definition of checkpoint blockade immunotherapy as therapeutic agents that interfere with inhibitory $\mathrm{T}$ cell surface receptorligand engagement, we will consider only inhibitory $\mathrm{T}$ cell surface receptors and their downstream immune-inhibitory pathways to be immune checkpoints.

The multitude of inhibitory pathways that play a critical role in maintaining self-tolerance and regulating the duration and amplitude of the immune response are called immune checkpoints.

Tumors have been shown to adapt and upregulate many these immune-inhibitory pathways to evade immune detection and destruction. An important example of this is the increased expression of the inhibitory ligands that modulate T-effector functions, which has been observed in various types of cancers.

In contrast with most antibodies currently used in cancer therapy which target tumor cells, antibodies for immune checkpoint blockade target lymphocyte receptors and their ligands which are present on the surface of APCs as well as cancerous and normal cells in peripheral tissues. When these antibodies bind their targets, they prevent the normal ligand-receptor interaction that would initiate an important immune-inhibitory pathway. By knocking out a critical pathway used by tumor cells to evade the immune system, these therapies effectively release the brakes on the immune system, lowering the immune threshold and enabling the development of an anti-tumor immune response. Antibodies developed to inhibit CTLA4 and PD-1 are revolutionizing cancer immunotherapy and have brought us into the era of Checkpoint Blockade Immunotherapy.

CTLA-4 was the first immune-checkpoint antigen to be targeted in CBI, and clinical testing of ipilimumab and tremelimumab, two humanized CTLA-4 antibodies, began in 2000 (70). Ipilimumab became FDA approved for the treatment of advanced melanoma in 2011, and treatment with this drug showed incredible results (189). In a landmark phase 3 study on Ipilimumab for the treatment of advanced melanoma by Hodi et al. Ipilimumab alone demonstrated a disease control rate of $28.5 \%$, and 1 and 2-year survival rates of 45.6 and $23.5 \%$, respectively (189). The impressive effects on long-term survival also supported the idea that immunotherapies could potentially re-educate the immune system to induce anti-tumor responses that are sustained long after completion of therapy. By blocking CTLA-4 signaling the level of co-stimulation required to activate the CD28 proimmunogenic pathway is decreased, thus directly reducing the threshold for activation at this step. The early success of CTLA-4 blockade revealed the potential of CBI and how it could change the meaning of being diagnosed with advanced melanoma.

Antibodies that target the PD-1/PD-L1 pathway have also significantly improved patient outcomes in multiple clinical 
studies (69). Analogously to anti-CTLA-4, by blocking PD-1 signaling the existing co-stimulatory factors and TCR signaling can more readily activate T-cells, thus directly reducing the threshold for activation at this step. Two such antibodies that have been extensively studied are pembrolizumab and nivolumab. The KEYNOTE-001 phase I study of 173 patients treated with pembrolizumab for advanced or unresectable melanoma that had progressed on ipilimumab and a BRAF inhibitor showed an overall response rate (ORR) of 26\%(190). This study lead to FDA approval of the first anti-PD-1 antibody, pembrolizumab, for advanced or unresectable melanoma. Several months later, the results of the CheckMate 037 trial supported FDA approval of nivolumab as secondline therapy for unresectable or metastatic melanoma (191). The phase II and III trials of PD-1 inhibitors in melanoma that followed, including KEYNOTE-006, KEYNOTE-002, CheckMate 037, CheckMate 069, and CheckMate 067, provided the basis to expand FDA approval of these PD1 inhibitors as first-line therapy for untreated advanced melanoma regardless of BRAF mutation status, for ipilimumabrefractory melanoma, and in combination with ipilimumab as first-line therapy for unresectable or metastatic melanoma (nivolumab) $(71,192,193)$.

These studies in melanoma served as the impetus for expanding the clinical application of PD-1 inhibitors and exploring CBI in various tumor types. Further studies lead to FDA approval of pembrolizumab for non-small cell lung cancer (NSCLC) in 2015, head and neck squamous cell carcinoma (HNSCC) in 2016, Hodgkin lymphoma, urothelial carcinoma, all tumors with high microsatellite instability (MSIhigh), and gastric cancer in 2017. Nivolumab also received FDA approval for treatment of renal cell carcinoma (RCC) in 2015, Hodgkin lymphoma and HNSCC in 2016, and urothelial, MSI-high colorectal, and hepatocellular caricinoma (HCC) in 2017 (194).

The efficacy of anti-PD-L1 antibodies, which inhibit the PD-1/ PD-L1 axis from a different angle, is also being studied. Three PD-L1 inhibitors, atezolizumab, avelumab, and durvalumab, have been clinically tested. Atezolizumab was approved as second-line therapy for metastatic NSCLC in 2016 after the results of the POPLAR and OAK trials $(195,196)$. A phase II trial studying atezolizumab for urothelial cancer (UC), IMVigo 210, showed an overall response rate (ORR) of $15 \%$ in patients with advanced and metastatic platinumbased chemotherapy-refractory UC, a significant improvement over the historical 10\% response rate. (197). A separate cohort of the IMVigor 210 trial showed similar results in patients with treatment-naïve metastatic UC, leading to the accelerated approval of atezolizumab as first-line therapy for cisplatinineligible advanced and metastatic UC (198). Avelumab and durvalumab, two other anti-PD-L1 antibodies, were approved for merkel cell carcinoma (MCC) and UC, and UC, respectively in 2017 (199-201). These drugs, as well as the other PD1 and PD-L1 inhibitors, are continuing to be studied in the clinic in various tumor types and in combination with other cancer therapies.

\section{AUTOIMMUNITY AND IMMUNE RELATED ADVERSE EVENTS (irAEs)}

The use of cancer immunotherapies has led to the recognition and characterization of a new category of side effects, immunerelated adverse events (irAEs). The irAEs of CBI are relatively mild and rare compared to those seen in other systemic cancer immunotherapies. Of the CBIs, anti-CTLA- 4 is associated with the most frequent and severe irAEs. Severe drug-related irAEs were seen in $15-30 \%$ of patients on anti-CTLA- 4 therapy, sometimes even resulting in fatalities (202). These irAEs included inflammation of normal tissues such as the gut, skin, and endocrine glands. The occurrence of irAEs in individuals with no previous history of autoimmunity reflects the ability of CBI to decrease the threshold of immune stimulation required to elicit an immune response. In contrast to CTLA-4, PD-1 blockade is thought to act primarily within the tumor microenvironment and has been associated with fewer and less severe irAEs in the clinic.

Differences in response to anti-CTLA-4 therapy or antiPD-1 therapy are reflected in knockout mouse models. Mice deficient in CTLA-4 die from lymphoproliferation, while mice lacking $P D-1$ have more model-dependent autoimmunity, such as arthritis and cardiomyopathy. These findings translate to differences in irAE severity in the clinic. PD-1 was first suspected of playing a role in the regulation of T-cell tolerance and autoimmunity when Nishimura et al. observed that PD-1 knockout mice developed mild glomerulonephritis and detectable autoantibodies, mimicking late onset lupuslike disease (203). Organ-specific toxic effects are observed in patients treated with anti-PD-1 and anti-CTLA-4. Colitis and hypophysitis are more common with anti-CTLA- 4 therapy, while pneumonitis and thyroiditis appear to be more common with anti-PD-1 therapy. This suggests that these therapies throw off the negative regulation in peripheral tissues. irAEs can act as a gauge to measure how therapy is shifting the balance between inflammation and tolerance.

Whether the severity of autoimmune side effects correlates with efficacy of CBI induced antitumor responses is an important question. Several studies have shown that patients with more irAEs also have higher response rates. A recent retrospective study of 134 patients with NSCLC treated with nivolumab (anti-PD-1 antibody) found that the development of irAEs was associated with increased overall survival (204). Still, it is not clear what causes the variation in irAEs between patients. It is possible that germline genetic factors and gastrointestinal microbiologic composition can affect baseline host immunity. Certain genes have been shown to increase the risk of autoimmune diseases and studies have just begun to investigate whether these genetic factors increase the risk of irAEs. In addition, it has been demonstrated that presence of bacteria from the Bacteroidetes phylum is correlated with reduced rates of ipilimumab-induced colitis. It may be possible to skew the immune response toward anti-cancer effector functions by increasing the cancer antigen load via combinatorial treatments with chemotherapy and radiation therapy, however, how to achieve only an anticancer immune response while completely avoiding irAEs is 
not yet clear. A multitude of factors can influence the presence and severity of irAEs, therefore, the general consensus is that irAEs are not a necessary outcome of an efficient CBI-induced antitumor response, but that their presence may be indicative of better response to $\mathrm{CBI}$ in some patients.

\section{CONCLUSION}

In conclusion, with the success of checkpoint blockade immunotherapy we now have the capability to robustly activate the immune system and break self-tolerance to induce anti-tumor immunity and/or auto-immunity. Each individual likely has a baseline threshold for immune activation against self and foreign antigens which is a function of multiple complex and interdependent regulatory mechanisms. A better understanding of these immuno-regulatory pathways and activation thresholds is needed to guide rationale and strategic use of combinatorial therapies that enhance anti-tumor immune

\section{REFERENCES}

1. Chuang TH, Ulevitch RJ. Triad3A, an E3 ubiquitin-protein ligase regulating Toll-like receptors. Nat Immunol. (2004) 5:495-502. doi: 10.1038/ ni1066

2. Mansell A, Smith R, Doyle SL, Gray P, Fenner JE, Crack PJ, et al. Suppressor of cytokine signaling 1 negatively regulates Toll-like receptor signaling by mediating Mal degradation. Nat Immunol. (2006) 7:148-55. doi: $10.1038 /$ ni1299

3. Song XT, Evel-Kabler K, Rollins L, Aldrich M, Gao F, Huang XF, et al. An alternative and effective HIV vaccination approach based on inhibition of antigen presentation attenuators in dendritic cells. PLoS Med. (2006) 3:e11. doi: 10.1371/journal.pmed.0030011

4. Wertz IE, O’Rourke KM, Zhou H, Eby M, Aravind L, Seshagiri S, et al. De-ubiquitination and ubiquitin ligase domains of A20 downregulate NF-kappaB signalling. Nature. (2004) 430:694-9. doi: 10.1038/nature 02794

5. Boone DL, Turer EE, Lee EG, Ahmad RC, Wheeler MT, Tsui C, et al. The ubiquitin-modifying enzyme A20 is required for termination of Toll-like receptor responses. Nat Immunol. (2004) 5:1052-60. doi: 10.1038/ni1110

6. Desterro JM, Rodriguez MS, Hay RT. SUMO-1 modification of IkappaBalpha inhibits NF-kappaB activation. Mol Cell. (1998) 2:233-9. doi: 10.1016/S1097-2765(00)80133-1

7. Huang TT, Wuerzberger-Davis SM, Wu ZH, Miyamoto S. Sequential modification of NEMO/IKKgamma by SUMO-1 and ubiquitin mediates NF-kappaB activation by genotoxic stress. Cell. (2003) 115:565-76. doi: 10.1016/S0092-8674(03)00895-X

8. Kobayashi K, Hernandez LD, Galán JE, Janeway CA, Medzhitov R, Flavell RA. IRAK-M is a negative regulator of Toll-like receptor signaling. Cell. (2002) 110:191-202. doi: 10.1016/S0092-8674(02)00827-9

9. Burns K, Janssens S, Brissoni B, Olivos N, Beyaert R, Tschopp J. Inhibition of interleukin 1 receptor/Toll-like receptor signaling through the alternatively spliced, short form of MyD88 is due to its failure to recruit IRAK-4. J Exp Med. (2003) 197:263-8. doi: 10.1084/jem.20021790

10. Brint EK, $\mathrm{Xu} \mathrm{D}$, Liu $\mathrm{H}$, Dunne A, McKenzie AN, O’Neill LA, et al. ST2 is an inhibitor of interleukin 1 receptor and Toll-like receptor 4 signaling and maintains endotoxin tolerance. Nat Immunol. (2004) 5:373-9. doi: $10.1038 /$ ni1050

11. Hoshino K, Kashiwamura S, Kuribayashi K, Kodama T, Tsujimura T, Nakanishi K, et al. The absence of interleukin 1 receptor-related T1/ST2 does not affect $\mathrm{T}$ helper cell type 2 development and its effector function. $J$ Exp Med. (1999) 190:1541-8. doi: 10.1084/jem.190.10.1541 responses while limiting immune related toxicity. The threshold model we describe here provides a conceptual framework for understanding activation of immunity, tumor responses, and toxicity in the era of checkpoint blockade immunotherapy.

\section{AUTHOR CONTRIBUTIONS}

KG, VW, S-YC, and AS performed the scientific literature search, wrote the review, and interpreted the data. KG, S-YC, and AS produced the figures. KG, SK, VW, SP, EC, S-YC, PS, SS, and AS provided critical review of the manuscript and approved the final manuscript.

\section{FUNDING}

This work was supported in part by National Institute of Health (1KL2TR001444) to University of California at San Diego Clinical and Translational Research Institute.
12. Wald D, Qin J, Zhao Z, Qian Y, Naramura M, Tian L, et al. SIGIRR, a negative regulator of Toll-like receptor-interleukin 1 receptor signaling. Nat Immunol. (2003) 4:920-7. doi: 10.1038/ni968

13. Divanovic S, Trompette A, Atabani SF, Madan R, Golenbock DT, Visintin A, et al. Negative regulation of Toll-like receptor 4 signaling by the Toll-like receptor homolog RP105. Nat Immunol. (2005) 6:571-8. doi: 10.1038/ni1198

14. Iwami KI, Matsuguchi T, Masuda A, Kikuchi T, Musikacharoen T, Yoshikai Y. Cutting edge: naturally occurring soluble form of mouse Toll-like receptor 4 inhibits lipopolysaccharide signaling. J Immunol. (2000) 165:6682-6. doi: 10.4049/jimmunol.165.12.6682

15. LeBouder E, Rey-Nores JE, Rushmere NK, Grigorov M, Lawn SD, Affolter M, et al. Soluble forms of Toll-like receptor (TLR)2 capable of modulating TLR2 signaling are present in human plasma and breast milk. J Immunol. (2003) 171:6680-9. doi: 10.4049/jimmunol.171.12.6680

16. Klement JF, Rice NR, Car BD, Abbondanzo SJ, Powers GD, Bhatt PH, et al. IkappaBalpha deficiency results in a sustained NF-kappaB response and severe widespread dermatitis in mice. Mol Cell Biol. (1996) 16:2341-9. doi: 10.1128/MCB.16.5.2341

17. Lawrence T, Bebien M, Liu GY, Nizet V, Karin M. IKKalpha limits macrophage NF-kappaB activation and contributes to the resolution of inflammation. Nature. (2005) 434:1138-43. doi: 10.1038/nature03491

18. Senftleben U, Cao Y, Xiao G, Greten FR, Krähn G, Bonizzi G, et al. Activation by IKKalpha of a second, evolutionary conserved, NF-kappa B signaling pathway. Science. (2001) 293:1495-9. doi: 10.1126/science.1062677

19. Lin L, Spoor MS, Gerth AJ, Brody SL, Peng SL. Modulation of Th1 activation and inflammation by the NF-kappaB repressor Foxj1. Science. (2004) 303:1017-20. doi: 10.1126/science.1093889

20. Lin L, Hron JD, Peng SL. Regulation of NF-kappaB, Th activation, and autoinflammation by the forkhead transcription factor Foxo3a. Immunity. (2004) 21:203-13. doi: 10.1016/j.immuni.2004.06.016

21. Chatila TA, Blaeser F, Ho N, Lederman HM, Voulgaropoulos C, Helms $\mathrm{C}$, et al. JM2, encoding a fork head-related protein, is mutated in $\mathrm{X}$ linked autoimmunity-allergic disregulation syndrome. J Clin Invest. (2000) 106:R75-81. doi: 10.1172/JCI11679

22. Bennett CL, Christie J, Ramsdell F, Brunkow ME, Ferguson PJ, Whitesell $\mathrm{L}$, et al. The immune dysregulation, polyendocrinopathy, enteropathy, $\mathrm{X}$ linked syndrome (IPEX) is caused by mutations of FOXP3. Nat Genet. (2001) 27:20-1. doi: 10.1038/83713

23. Brunkow ME, Jeffery EW, Hjerrild KA, Paeper B, Clark LB, Yasayko SA, et al. Disruption of a new forkhead/winged-helix protein, scurfin, results in the fatal lymphoproliferative disorder of the scurfy mouse. Nat Genet. (2001) 27:68-73. doi: $10.1038 / 83784$ 
24. Fontenot JD, Gavin MA, Rudensky AY. Foxp3 programs the development and function of CD4+CD25+ regulatory T cells. Nat Immunol. (2003) 4:330-6. doi: 10.1038/ni904

25. Šošić D, Richardson JA, Yu K, Ornitz DM, Olson EN. Twist regulates cytokine gene expression through a negative feedback loop that represses NF-kappaB activity. Cell. (2003) 112:169-80. doi: 10.1016/S0092-8674(03)00002-3

26. Chi H, Barry SP, Roth RJ, Wu JJ, Jones EA, Bennett AM, et al. Dynamic regulation of pro- and anti-inflammatory cytokines by MAPK phosphatase 1 (MKP-1) in innate immune responses. Proc Natl Acad Sci USA. (2006) 103:2274-9. doi: 10.1073/pnas.0510965103

27. Zhao Q, Wang X, Nelin LD, Yao Y, Matta R, Manson ME, et al. MAP kinase phosphatase 1 controls innate immune responses and suppresses endotoxic shock. J Exp Med. (2006) 203:131-40. doi: 10.1084/jem.20051794

28. Zhang Y, Blattman JN, Kennedy NJ, Duong J, Nguyen T, Wang Y, et al. Regulation of innate and adaptive immune responses by MAP kinase phosphatase 5. Nature. (2004) 430:793-7. doi: 10.1038/nature02764

29. Yasuda T, Shirakata M, Iwama A, Ishii A, Ebihara Y, Osawa M, et al. Role of Dok-1 and Dok-2 in myeloid homeostasis and suppression of leukemia. J Exp Med. (2004) 200:1681-7. doi: 10.1084/jem.20041247

30. Shinohara H, Inoue A, Toyama-Sorimachi N, Nagai Y, Yasuda T, Suzuki H, et al. Dok-1 and Dok-2 are negative regulators of lipopolysaccharide-induced signaling. J Exp Med. (2005) 201:333-9. doi: 10.1084/jem.20041817

31. Conner DA, Mathier MA, Mortensen RM, Christe M, Vatner SF, Seidman $\mathrm{CE}$, et al. beta-Arrestin1 knockout mice appear normal but demonstrate altered cardiac responses to beta-adrenergic stimulation. Circ Res. (1997) 81:1021-6. doi: 10.1161/01.RES.81.6.1021

32. Gao H, Sun Y, Wu Y, Luan B, Wang Y, Qu B, et al. Identification of betaarrestin2 as a $G$ protein-coupled receptor-stimulated regulator of NF-kappaB pathways. Mol Cell. (2004) 14:303-17. doi: 10.1016/S1097-2765(04)00216-3

33. Wang Y, Tang Y, Teng L, Wu Y, Zhao X, Pei G. Association of beta-arrestin and TRAF6 negatively regulates Toll-like receptor-interleukin 1 receptor signaling. Nat Immunol. (2006) 7:139-47. doi: 10.1038/ni1294

34. Zhang G, Ghosh S. Negative regulation of toll-like receptormediated signaling by Tollip. J Biol Chem. (2002) 277:7059-65. doi: 10.1074/jbc.M109537200

35. Watanabe T, Kitani A, Murray PJ, Strober W. NOD2 is a negative regulator of Toll-like receptor 2-mediated T helper type 1 responses. Nat Immunol. (2004) 5:800-8. doi: 10.1038/ni1092

36. Kobayashi KS, Chamaillard M, Ogura Y, Henegariu O, Inohara N, Nu-ez G, et al. Nod2-dependent regulation of innate and adaptive immunity in the intestinal tract. Science. (2005) 307:731-4. doi: 10.1126/science.1104911

37. Marine JC, Topham DJ, McKay C, Wang D, Parganas E, Stravopodis D, et al. SOCS1 deficiency causes a lymphocyte-dependent perinatal lethality. Cell. (1999) 98:609-16. doi: 10.1016/S0092-8674(00)80048-3

38. Alexander WS, Starr R, Fenner JE, Scott CL, Handman E, Sprigg NS, et al. SOCS1 is a critical inhibitor of interferon gamma signaling and prevents the potentially fatal neonatal actions of this cytokine. Cell. (1999) 98:597-608. doi: 10.1016/S0092-8674(00)80047-1

39. Kinjyo I, Hanada T, Inagaki-Ohara K, Mori H, Aki D, Ohishi M, et al. SOCS1/JAB is a negative regulator of LPS-induced macrophage activation. Immunity. (2002) 17:583-91. doi: 10.1016/S1074-7613(02)00446-6

40. Nakagawa R, Naka T, Tsutsui H, Fujimoto M, Kimura A, Abe T, et al. SOCS1 participates in negative regulation of LPS responses. Immunity. (2002) 17:677-87. doi: 10.1016/S1074-7613(02)00449-1

41. Hanada T, Yoshida H, Kato S, Tanaka K, Masutani K, Tsukada J, et al. Suppressor of cytokine signaling-1 is essential for suppressing dendritic cell activation and systemic autoimmunity. Immunity. (2003) 19:437-50. doi: 10.1016/S1074-7613(03)00240-1

42. Greenhalgh CJ, Miller ME, Hilton DJ, Lund PK. Suppressors of cytokine signaling: Relevance to gastrointestinal function and disease. Gastroenterology. (2002) 123:2064-81. doi: 10.1053/gast.2002.37068

43. Machado FS, Johndrow JE, Esper L, Dias A, Bafica A, Serhan CN, et al. Anti-inflammatory actions of lipoxin $\mathrm{A}(4)$ and aspirin-triggered lipoxin are SOCS-2 dependent. Nat Med. (2006) 12:330-4. doi: 10.1038/nm1355

44. Yasukawa H, Ohishi M, Mori H, Murakami M, Chinen T, Aki D, et al. IL-6 induces an anti-inflammatory response in the absence of SOCS3 in macrophages. Nat Immunol. (2003) 4:551-6. doi: 10.1038/ni938
45. Lang R, Pauleau AL, Parganas E, Takahashi Y, Mages J, Ihle JN, et al. SOCS3 regulates the plasticity of gp130 signaling. Nat Immunol. (2003) 4:546-50. doi: $10.1038 /$ ni 932

46. Croker BA, Krebs DL, Zhang JG, Wormald S, Willson TA, Stanley EG, et al. SOCS3 negatively regulates IL-6 signaling in vivo. Nat Immunol. (2003) 4:540-5. doi: 10.1038/ni931

47. Liu B, Mink S, Wong KA, Stein N, Getman C, Dempsey PW, et al. PIAS1 selectively inhibits interferon-inducible genes and is important in innate immunity. Nat Immunol. (2004) 5:891-8. doi: 10.1038/ni1104

48. Liu B, Yang R, Wong KA, Getman C, Stein N, Teitell MA, et al. Negative regulation of NF-kappaB signaling by PIAS1. Mol Cell Biol. (2005) 25:1113-23. doi: 10.1128/MCB.25.3.1113-112 3.2005

49. Shultz LD, Schweitzer PA, Rajan TV, Yi T, Ihle JN, Matthews RJ, et al. Mutations at the murine motheaten locus are within the hematopoietic cell protein-tyrosine phosphatase (Hcph) gene. Cell. (1993) 73:1445-54. doi: 10.1016/0092-8674(93)90369-2

50. Tsui HW, Siminovitch KA, de Souza L, Tsui FW. Motheaten and viable motheaten mice have mutations in the haematopoietic cell phosphatase gene. Nat Genet. (1993) 4:124-9. doi: 10.1038/ng0693-124

51. Qu CK, Nguyen S, Chen J, Feng GS. Requirement of Shp-2 tyrosine phosphatase in lymphoid and hematopoietic cell development. Blood. (2001) 97:911-4. doi: 10.1182/blood.V97.4.911

52. Tanaka T, Soriano MA, Grusby MJ. SLIM is a nuclear ubiquitin E3 ligase that negatively regulates STAT signaling. Immunity. (2005) 22:729-36. doi: 10.1016/j.immuni.2005.04.008

53. Sarkar S, Kalia V, Haining WN, Konieczny BT, Subramaniam S, Ahmed R. Functional and genomic profiling of effector CD8 T cell subsets with distinct memory fates. J Exp Med. (2008) 205:625-40. doi: 10.1084/jem.20071641

54. Sallusto F, Lenig D, Förster R, Lipp M, Lanzavecchia A. Two subsets of memory $\mathrm{T}$ lymphocytes with distinct homing potentials and effector functions. Nature. (1999) 401:708-12. doi: 10.1038/44385

55. Kaech SM, Ahmed R. Memory CD8+ T cell differentiation: initial antigen encounter triggers a developmental program in naive cells. Nat Immunol. (2001) 2:415-22. doi: 10.1038/87720

56. Wherry EJ, Ha SJ, Kaech SM, Haining WN, Sarkar S, Kalia V, et al. Molecular signature of $\mathrm{CD} 8+\mathrm{T}$ cell exhaustion during chronic viral infection. Immunity. (2007) 27:670-84. doi: 10.1016/j.immuni.2007. 09.006

57. Wherry EJ, Blattman JN, Murali-Krishna K, van der Most R, Ahmed R. Viral persistence alters CD8 T-cell immunodominance and tissue distribution and results in distinct stages of functional impairment. J Virol. (2003) 77:4911-27. doi: 10.1128/JVI.77.8.4911-4927.2003

58. Boni C, Fisicaro P, Valdatta C, Amadei B, Di Vincenzo P, Giuberti $\mathrm{T}$, et al. Characterization of hepatitis B virus (HBV)-specific T-cell dysfunction in chronic HBV infection. J Virol. (2007) 81:4215-25. doi: 10.1128/JVI.02844-06

59. Day CL, Kaufmann DE, Kiepiela P, Brown JA, Moodley ES, Reddy S, et al. PD-1 expression on HIV-specific T cells is associated with T-cell exhaustion and disease progression. Nature. (2006) 443:350-4. doi: 10.1038/nature05115

60. Peng G, Li S, Wu W, Tan X, Chen Y, Chen Z. PD-1 upregulation is associated with HBV-specific T cell dysfunction in chronic hepatitis B patients. Mol Immunol. (2008) 45:963-70. doi: 10.1016/j.molimm.2007.07.038

61. Akira S, Takeda K. Toll-like receptor signalling. Nat Rev Immunol. (2004) 4:499-511. doi: 10.1038/nri1391

62. Alexander WS, Hilton DJ. The role of suppressors of cytokine signaling (SOCS) Proteins in regulation of the immune response. Annu Rev Immunol. (2004) 22:503-29. doi: 10.1146/annurev.immunol.22.091003.090312

63. Beutler B. Inferences, questions and possibilities in Toll-like receptor signalling. Nature. (2004) 430:257-63. doi: 10.1038/nature02761

64. Kubo M, Hanada T, Yoshimura A. Suppressors of cytokine signaling and immunity. Nat Immunol. (2003) 4:1169-76. doi: 10.1038/ni1012

65. Liew FY, Xu D, Brint EK, O'Neill LA. Negative regulation of toll-like receptor-mediated immune responses. Nat Rev Immunol. (2005) 5:446-58. doi: $10.1038 /$ nri1630

66. Patel SJ, Sanjana NE, Kishton RJ, Eidizadeh A, Vodnala SK, Cam M, et al. Identification of essential genes for cancer immunotherapy. Nature. (2017) 548:537-42. doi: 10.1038/nature23477 
67. Doria A, Canova M, Tonon M, Zen M, Rampudda E, Bassi N, et al. Infections as triggers and complications of systemic lupus erythematosus. Autoimmun Rev. (2008) 8:24-8. doi: 10.1016/j.autrev.2008.07.019

68. Decker WK, da Silva RF, Sanabria MH, Angelo LS, Guimarães F, Burt BM, et al. Cancer Immunotherapy: Historical Perspective of a Clinical Revolution and Emerging Preclinical Animal Models. Front Immunol. (2017) 8:829. doi: 10.3389/fimmu.2017.00829

69. Brahmer JR, Drake CG, Wollner I, Powderly JD, Picus J, Sharfman WH, et al. Phase I study of single-agent anti-programmed death1 (MDX-1106) in refractory solid tumors: safety, clinical activity, pharmacodynamics, and immunologic correlates. J Clin Oncol. (2010) 28:3167-75. doi: 10.1200/JCO.2009.26.7609

70. Ribas A, Camacho LH, Lopez-Berestein G, Pavlov D, Bulanhagui CA, Millham R, et al. Antitumor activity in melanoma and anti-self responses in a phase I trial with the anti-cytotoxic $\mathrm{T}$ lymphocyte-associated antigen 4 monoclonal antibody CP-675,206. J Clin Oncol. (2005) 23:8968-77. doi: 10.1200/JCO.2005.01.109

71. Postow MA, Chesney J, Pavlick AC, Robert C, Grossmann K, McDermott D, et al. Nivolumab and ipilimumab versus ipilimumab in untreated melanoma. N Engl J Med. (2015) 372:2006-17. doi: 10.1056/NEJMoa1414428

72. Sharma P, Hu-Lieskovan S, Wargo JA, Ribas A. Primary, Adaptive, and Acquired Resistance to Cancer Immunotherapy. Cell. (2017) 168:707-723. doi: 10.1016/j.cell.2017.01.017

73. Arakaki R, Yamada A, Kudo Y, Hayashi Y, Ishimaru N. Mechanism of activation-induced cell death of $\mathrm{T}$ cells and regulation of FasL expression. Crit Rev Immunol. (2014) 34:301-14. doi: 10.1615/CritRevImmunol.2014009988

74. Banchereau J, Steinman RM. Dendritic cells and the control of immunity. Nature. (1998) 392:245-52. doi: 10.1038/32588

75. Steinman RM, Hawiger D, Nussenzweig MC. Tolerogenic dendritic cells. Annu Rev Immunol. (2003) 21:685-711. doi: 10.1146/annurev.immunol.21.120601.141040

76. Janeway CA Jr, Medzhitov R. Innate immune recognition. Annu Rev Immunol. (2002) 20:197-216. doi: 10.1146/annurev.immunol.20.083001.084359

77. Evel-Kabler K, Song XT, Aldrich M, Huang XF, Chen SY. SOCS1 restricts dendritic cells' ability to break self tolerance and induce antitumor immunity by regulating IL-12 production and signaling. J Clin Invest. (2006) 116:90100. doi: $10.1172 /$ JCI26169

78. Shen L, Evel-Kabler K, Strube R, Chen SY. Silencing of SOCS1 enhances antigen presentation by dendritic cells and antigen-specific anti-tumor immunity. Nat Biotechnol. (2004) 22:1546-53. doi: 10.1038/nbt1035

79. Grohmann U, Belladonna ML, Bianchi R, Orabona C, Ayroldi E, Fioretti $\mathrm{MC}$, et al. IL-12 acts directly on DC to promote nuclear localization of NFkappaB and primes DC for IL-12 production. Immunity. (1998) 9:315-23. doi: 10.1016/S1074-7613(00)80614-7

80. Gautier G, Humbert M, Deauvieau F, Scuiller M, Hiscott J, Bates EE, et al. A type I interferon autocrine-paracrine loop is involved in Toll-like receptorinduced interleukin-12p70 secretion by dendritic cells. J Exp Med. (2005) 201:1435-46. doi: 10.1084/jem.20041964

81. Hawiger D, Inaba K, Dorsett $\mathrm{Y}$, Guo M, Mahnke K, Rivera $\mathrm{M}$, et al. Dendritic cells induce peripheral T cell unresponsiveness under steady state conditions in vivo. J Exp Med. (2001) 194:769-79. doi: 10.1084/jem.19 4.6 .769

82. Liu K, Iyoda T, Saternus M, Kimura Y, Inaba K, Steinman RM. Immune tolerance after delivery of dying cells to dendritic cells in situ. J Exp Med. (2002) 196:1091-7. doi: 10.1084/jem.20021215

83. Gilliet M, Liu YJ. Generation of human CD8 T regulatory cells by CD40 ligand-activated plasmacytoid dendritic cells. J Exp Med. (2002) 195:695704. doi: 10.1084/jem.20011603

84. Wakkach A, Fournier N, Brun V, Breittmayer JP, Cottrez F, Groux $\mathrm{H}$. Characterization of dendritic cells that induce tolerance and $\mathrm{T}$ regulatory 1 cell differentiation in vivo. Immunity. (2003) 18:605-17. doi: 10.1016/S1074-7613(03)00113-4

85. Ochando JC, Homma C, Yang Y, Hidalgo A, Garin A, Tacke F, et al. Alloantigen-presenting plasmacytoid dendritic cells mediate tolerance to vascularized grafts. Nat Immunol. (2006) 7:652-62. doi: 10.1038/ni1333
86. Döhler A, Schneider T, Eckert I, Ribechini E, Andreas N, Riemann M, et al RelB + Steady-State Migratory Dendritic Cells Control the Peripheral Pool of the Natural Foxp3+ Regulatory T Cells. Front Immunol. (2017) 8:726. doi: 10.3389/fimmu.2017.00726

87. Williams JW, Tjota MY, Clay BS, Vander Lugt B, Bandukwala HS, Hrusch CL, et al. Transcription factor IRF4 drives dendritic cells to promote Th2 differentiation. Nat Commun. (2013) 4:2990 doi: 10.1038/ncomms3990

88. Vander Lugt B, Riddell J, Khan AA, Hackney JA, Lesch J, DeVoss $\mathrm{J}$, et al. Transcriptional determinants of tolerogenic and immunogenic states during dendritic cell maturation. J Cell Biol. (2017) 216:779-792. doi: $10.1083 /$ jcb. 201512012

89. Hontelez S, Ansems M, Karthaus N, Zuidscherwoude M, Looman MW, Triantis V, et al. Dendritic cell-specific transcript: dendritic cell marker and regulator of TLR-induced cytokine production. J Immunol. (2012) 189:13845. doi: 10.4049/jimmunol.1103709

90. Søndergaard JN, van Heeringen SJ, Looman MWG, Tang C, Triantis V, Louche $\mathrm{P}$, et al. Dendritic cells actively limit interleukin-10 production under inflammatory conditions via DC-SCRIPT and dual-specificity phosphatase 4. Front Immunol. (2018) 9:1420. doi: 10.3389/fimmu.2018.01420

91. Mellor AL, Munn DH. IDO expression by dendritic cells: tolerance and tryptophan catabolism. Nat Rev Immunol. (2004) 4:762-74. doi: $10.1038 /$ nril 457

92. Munn DH, Sharma MD, Lee JR, Jhaver KG, Johnson TS, Keskin $\mathrm{DB}$, et al. Potential regulatory function of human dendritic cells expressing indoleamine 2,3-dioxygenase. Science. (2002) 297:1867-70. doi: 10.1126/science.1073514

93. Miller CL, Llenos IC, Dulay JR, Barillo MM, Yolken RH, Weis S. Expression of the kynurenine pathway enzyme tryptophan 2,3-dioxygenase is increased in the frontal cortex of individuals with schizophrenia. Neurobiol Dis. (2004) 15:618-29. doi: 10.1016/j.nbd.2003.12.015

94. Pilotte L, Larrieu P, Stroobant V, Colau D, Dolusic E, Frédérick $\mathrm{R}$, et al. Reversal of tumoral immune resistance by inhibition of tryptophan 2,3-dioxygenase. Proc Natl Acad Sci USA. (2012) 109:2497-502. doi: 10.1073/pnas.1113873109

95. Molinier-Frenkel V, Castellano F. Immunosuppressive enzymes in the tumor microenvironment. FEBS Lett. (2017) 591:3135-3157. doi: 10.1002/1873-3468.12784

96. Platten M, von Knebel Doeberitz N, Oezen I, Wick W, Ochs K. Cancer Immunotherapy by Targeting IDO1/TDO and Their Downstream Effectors. Front Immunol. (2014) 5.

97. Chen L. Co-inhibitory molecules of the B7-CD28 family in the control of T-cell immunity. Nat Rev Immunol. (2004) 4:336-47. doi: 10.1038/nri1349

98. Greenwald RJ, Freeman GJ, Sharpe AH. The B7 family revisited. Annu Rev Immunol. (2005) 23:515-48. doi: 10.1146/annurev.immunol.23.021704.115611

99. Cantrell D. T cell antigen receptor signal transduction pathways. Annu Rev Immunol. (1996) 14:259-74. doi: 10.1146/annurev.immunol.14.1.259

100. Kane LP, Lin J, Weiss A. Signal transduction by the TCR for antigen. Curr Opin Immunol. (2000) 12:242-9. doi: 10.1016/S0952-7915(00) 00083-2

101. Liu JO. The yins of T cell activation. Sci STKE. (2005) 2005:re1.

102. Shuai K, Liu B. Regulation of JAK-STAT signalling in the immune system. Nat Rev Immunol. (2003) 3:900-11. doi: 10.1038/nri1226

103. Sakaguchi S. Naturally arising Foxp3-expressing CD25+CD4+ regulatory $\mathrm{T}$ cells in immunological tolerance to self and non-self. Nat Immunol. (2005) 6:345-52. doi: 10.1038/ni1178

104. Fontenot JD, Rudensky AY. A well adapted regulatory contrivance: regulatory $\mathrm{T}$ cell development and the forkhead family transcription factor Foxp3. Nat Immunol. (2005) 6:331-7. doi: 10.1038/ni1179

105. Wildin RS, Ramsdell F, Peake J, Faravelli F, Casanova JL, Buist N, et al. $X$-linked neonatal diabetes mellitus, enteropathy and endocrinopathy syndrome is the human equivalent of mouse scurfy. Nat Genet. (2001) 27:18-20. doi: 10.1038/83707

106. Walker MR, Kasprowicz DJ, Gersuk VH, Benard A, Van Landeghen M, Buckner JH, et al. Induction of FoxP3 and acquisition of T regulatory activity by stimulated human CD4+CD25- T cells. J Clin Invest. (2003) 112:1437-43. doi: 10.1172/JCI19441 
107. Coffer PJ, Burgering BM. Forkhead-box transcription factors and their role in the immune system. Nat Rev Immunol. (2004) 4:889-99. doi: $10.1038 /$ nri1488

108. Schubert LA, Jeffery E, Zhang Y, Ramsdell F, Ziegler SF. Scurfin (FOXP3) acts as a repressor of transcription and regulates $\mathrm{T}$ cell activation. J Biol Chem. (2001) 276:37672-9. doi: 10.1074/jbc.M104521200

109. Jiang H, Chess L. Regulation of immune responses by T cells. N Engl J Med. (2006) 354:1166-76. doi: 10.1056/NEJMra055446

110. Gagliani N, Magnani CF, Huber S, Gianolini ME, Pala M, Licona-Limon P, et al. Coexpression of CD49b and LAG-3 identifies human and mouse $\mathrm{T}$ regulatory type 1 cells. Nat Med. (2013) 19:739-46. doi: 10.1038/nm.3179

111. Roncarolo MG, Gregori S, Bacchetta R, Battaglia M. Tr1 cells and the counter-regulation of immunity: natural mechanisms and therapeutic applications. Curr Top Microbiol Immunol. (2014) 380:39-68. doi: 10.1007/978-3-662-43492-5_3

112. Magnani CF, Alberigo G, Bacchetta R, Serafini G, Andreani M, Roncarolo MG, et al. Killing of myeloid APCs via HLA class I, CD2 and CD226 defines a novel mechanism of suppression by human Tr1 cells. Eur J Immunol. (2011) 41:1652-62. doi: 10.1002/eji.201041120

113. Karwacz K, Miraldi ER, Pokrovskii M, Madi A, Yosef N, Wortman I, et al. Critical role of IRF1 and BATF in forming chromatin landscape during type 1 regulatory cell differentiation. Nat Immunol. (2017) 18:412-421. doi: $10.1038 /$ ni.3683

114. Huang W, Solouki S, Koylass N, Zheng SG, August A. ITK signalling via the Ras/IRF4 pathway regulates the development and function of $\operatorname{Tr} 1$ cells. Nat Commun. (2017) 8:15871. doi: 10.1038/ncomms15871

115. Cretney E, Xin A, Shi W, Minnich M, Masson F, Miasari M, et al. The transcription factors Blimp-1 and IRF4 jointly control the differentiation and function of effector regulatory T cells. Nat Immunol. (2011) 12:304-11. doi: 10.1038/ni.2006

116. Churlaud G, Pitoiset F, Jebbawi F, Lorenzon R, Bellier B, Rosenzwajg M, et al. Human and Mouse CD8+CD25+FOXP3+ Regulatory T Cells at Steady State and during Interleukin-2 Therapy. Front Immunol. (2015) 6. doi: 10.3389/fimmu.2015.00171

117. Robb RJ, Lineburg KE, Kuns RD, Wilson YA, Raffelt NC, Olver $\mathrm{SD}$, et al. Identification and expansion of highly suppressive $\mathrm{CD} 8(+)$ FoxP3(+) regulatory $\mathrm{T}$ cells after experimental allogeneic bone marrow transplantation. Blood. (2012) 119:5898-908. doi: 10.1182/blood-2011-12-396119

118. Kim HJ, Verbinnen B, Tang X, Lu L, Cantor H. Inhibition of follicular T-helper cells by $\mathrm{CD} 8(+)$ regulatory $\mathrm{T}$ cells is essential for self tolerance. Nature. (2010) 467:328-32. doi: 10.1038/nature09370

119. Kiniwa Y, Miyahara Y, Wang HY, Peng W, Peng G, Wheeler TM, et al. CD8+ Foxp3+ regulatory $\mathrm{T}$ cells mediate immunosuppression in prostate cancer. Clin Cancer Res. (2007) 13:6947-58. doi: 10.1158/1078-0432.CCR-07-0842

120. Chen X, Liu Q, Xiang AP. CD8+CD28- T cells: not only age-related cells but a subset of regulatory T cells. Cell Mol Immunol. (2018) 15:734. doi: $10.1038 / \mathrm{cmi} .2017 .153$

121. Agle K, Vincent BG, Piper C, Belle L, Zhou V, Shlomchik W, et al. Bim regulates the survival and suppressive capability of $\mathrm{CD} 8(+)$ FOXP3(+) regulatory $\mathrm{T}$ cells during murine GVHD. Blood (2018) 132:435-47. doi: 10.1182/blood-2017-09-807156

122. Kleijwegt FS, Laban S, Duinkerken G, Joosten AM, Zaldumbide A, Nikolic $\mathrm{T}$, et al. Critical role for TNF in the induction of human antigen-specific regulatory T cells by tolerogenic dendritic cells. J Immunol. (2010) 185:14128. doi: 10.4049/jimmunol.1000560

123. Ye LL, Wei XS, Zhang M, Niu YR, Zhou Q. The significance of tumor necrosis factor receptor type II in $\mathrm{CD} 8(+)$ regulatory $\mathrm{T}$ cells and CD8(+) effector T cells. Front Immunol. (2018) 9:583. doi: 10.3389/fimmu.2018.00583

124. Zhang S, Ke X, Zeng S, Wu M, Lou J, Wu L, et al. Analysis of CD8+ Treg cells in patients with ovarian cancer: a possible mechanism for immune impairment. Cell Mol Immunol. (2015) 12:580-91. doi: 10.1038/cmi.2015.57

125. Wu M, Chen X, Lou J, Zhang S, Zhang X, Huang L, et al. TGF$\beta 1$ contributes to CD8+ Treg induction through p38 MAPK signaling in ovarian cancer microenvironment. Oncotarget. (2016) 44534-44. doi: 10.18632 /oncotarget.10003
126. Chen Z, Han Y, Gu Y, Liu Y, Jiang Z, Zhang M, et al. CD11c(high)CD8+ regulatory $\mathrm{T}$ cell feedback inhibits $\mathrm{CD} 4 \mathrm{~T}$ cell immune response via Fas ligand-Fas pathway. J Immunol. (2013) 190:6145-54. doi: 10.4049/jimmunol.1300060

127. Mauri C, Bosma A. Immune regulatory function of B cells. Annu Rev Immunol. (2012) 30:221-41. doi: 10.1146/annurev-immunol-020711-074934

128. Rosser EC, Mauri C. Regulatory B cells: origin, phenotype, and function. Immunity. (2015) 42:607-12. doi: 10.1016/j.immuni.2015. 04.005

129. Shen P, Roch T, Lampropoulou V, O'Connor RA, Stervbo U, Hilgenberg E, et al. IL-35-producing B cells are critical regulators of immunity during autoimmune and infectious diseases. Nature. (2014) 507:366-70. doi: 10.1038/nature12979

130. Wolf SD, Dittel BN, Hardardottir F, Janeway CA. Experimental autoimmune encephalomyelitis induction in genetically B cell-deficient mice. J Exp Med. (1996) 184:2271-8. doi: 10.1084/jem.184.6.2271

131. Mauri $\mathrm{C}$, Menon $\mathrm{M}$. The expanding family of regulatory B cells. Int Immunol. (2015) 27:479-86. doi: 10.1093/intimm/dxv038

132. Zeng Z, Casta-o AR, Segelke BW, Stura EA, Peterson PA, Wilson IA. Crystal structure of mouse CD1: an MHC-like fold with a large hydrophobic binding groove. Science. (1997) 277:339-45. doi: 10.1126/science.277.53 24.339

133. Salio M, Silk JD, Jones EY, Cerundolo V. Biology of CD1- and MR1-restricted T cells. Annu Rev Immunol. (2014) 32:323-66. doi: 10.1146/annurev-immunol-032713-120243

134. Van Kaer L. alpha-Galactosylceramide therapy for autoimmune diseases: prospects and obstacles. Nat Rev Immunol. (2005) 5:31-42. doi: $10.1038 /$ nri1531

135. Oleinika K, Rosser EC, Matei DE, Nistala K, Bosma A, Drozdov I, et al. CD1d-dependent immune suppression mediated by regulatory $\mathrm{B}$ cells through modulations of iNKT cells. Nat Commun. (2018) 9:684. doi: 10.1038/s41467-018-02911-y

136. Fillatreau S, Sweenie CH, McGeachy MJ, Gray D, Anderton SM. B cells regulate autoimmunity by provision of IL-10. Nat Immunol. (2002) 3:944-50. doi: $10.1038 /$ ni 833

137. Mizoguchi A, Mizoguchi E, Takedatsu H, Blumberg RS, Bhan AK. Chronic intestinal inflammatory condition generates IL-10-producing regulatory B cell subset characterized by CD1d upregulation. Immunity. (2002) 16:21930. doi: 10.1016/S1074-7613(02)00274-1

138. Yanaba K, Bouaziz JD, Haas KM, Poe JC, Fujimoto M, Tedder TF. A regulatory B cell subset with a unique $\mathrm{CD} 1 \mathrm{dhiCD} 5+$ phenotype controls $\mathrm{T}$ cell-dependent inflammatory responses. Immunity. (2008) 28:639-50. doi: 10.1016/j.immuni.2008.03.017

139. Kalampokis I, Yoshizaki A, Tedder TF. IL-10-producing regulatory B cells (B10 cells) in autoimmune disease. Arthritis Res Ther. (2013) 15(Suppl 1):S1. doi: $10.1186 / a r 3907$

140. Yoshizaki A, Miyagaki T, DiLillo DJ, Matsushita T, Horikawa M, Kountikov EI, et al. Regulatory B cells control T-cell autoimmunity through IL-21-dependent cognate interactions. Nature. (2012) 491:264-8. doi: 10.1038/nature11501

141. Carter NA, Rosser EC, Mauri C. Interleukin-10 produced by B cells is crucial for the suppression of Th17/Th1 responses, induction of T regulatory type 1 cells and reduction of collagen-induced arthritis. Arthritis Res Ther. (2012) 14:R32. doi: 10.1186/ar3736

142. Maseda D, Smith SH, DiLillo DJ, Bryant JM, Candando KM, Weaver CT, et al. Regulatory B10 cells differentiate into antibody-secreting cells after transient IL-10 production in vivo. J Immunol. (2012) 188:1036-48. doi: 10.4049/jimmunol.1102500

143. Blair PA, Nore-a LY, Flores-Borja F, Rawlings DJ, Isenberg DA, Ehrenstein $\mathrm{MR}$, et al. CD19(+)CD24(hi)CD38(hi) B cells exhibit regulatory capacity in healthy individuals but are functionally impaired in systemic Lupus Erythematosus patients. Immunity. (2010) 32:129-40. doi: 10.1016/j.immuni.2009.11.009

144. Flores-Borja F, Bosma A, Ng D, Reddy V, Ehrenstein MR, Isenberg DA, et al. CD19+CD24hiCD38hi B cells maintain regulatory $\mathrm{T}$ cells while limiting TH1 and TH17 differentiation. Sci Transl Med. (2013) 5:173ra23. doi: $10.1126 /$ scitranslmed. 3005407 
145. Huang A, Cheng L, He M, Nie J, Wang J, Jiang K. Interleukin-35 on B cell and T cell induction and regulation. J Inflamm. (2017) 14:16. doi: 10.1186/s12950-017-0164-5

146. Egwuagu CE, Yu CR. Interleukin 35-producing B cells (i35-Breg): a new mediator of regulatory B-cell functions in CNS autoimmune diseases. Crit Rev Immunol. (2015) 35:49-57. doi: 10.1615/CritRevImmunol.2015012558

147. Niedbala W, Wei XQ, Cai B, Hueber AJ, Leung BP, McInnes IB, et al. IL-35 is a novel cytokine with therapeutic effects against collagen-induced arthritis through the expansion of regulatory $\mathrm{T}$ cells and suppression of Th17 cells. Eur J Immunol. (2007) 37:3021-9. doi: 10.1002/eji.200737810

148. Collison LW, Workman CJ, Kuo TT, Boyd K, Wang Y, Vignali KM, et al. The inhibitory cytokine IL-35 contributes to regulatory T-cell function. Nature. (2007) 450:566-9. doi: 10.1038/nature06306

149. Fogel O, Rivière E, Seror R, Nocturne G, Boudaoud S, Ly B, et al. Role of the IL-12/IL-35 balance in patients with Sjogren syndrome. J Allergy Clin Immunol. (2018) 142:258-268.e5. doi: 10.1016/j.jaci.2017.07.041

150. Singh K, Kadesjö E, Lindroos J, Hjort M, Lundberg M, Espes D, et al. Interleukin-35 administration counteracts established murine type 1 diabetes-possible involvement of regulatory T cells. Sci Rep. (2015) 5:12633. doi: 10.1038/srep12633

151. Guo H, Zhao N, Gao H, He X. Mesenchymal Stem Cells Overexpressing Interleukin-35 Propagate Immunosuppressive Effects in Mice. Scand J Immunol. (2017) 86:389-395. doi: 10.1111/sji.12613

152. Wang RX, Yu CR, Dambuza IM, Mahdi RM, Dolinska MB, Sergeev YV, et al. Interleukin-35 induces regulatory B cells that suppress autoimmune disease. Nat Med. (2014) 20:633-41. doi: 10.1038/nm.3554

153. Flodström-Tullberg M, Yadav D, Hägerkvist R, Tsai D, Secrest P, Stotland A, et al. Target cell expression of suppressor of cytokine signaling1 prevents diabetes in the NOD mouse. Diabetes. (2003) 52:2696-700. doi: $10.2337 /$ diabetes.52.11.2696

154. Nagata S. Apoptosis by death factor. Cell. (1997) 88:355-65. doi: 10.1016/S0092-8674(00)81874-7

155. Gao Y, Herndon JM, Zhang H, Griffith TS, Ferguson TA. Antiinflammatory effects of CD95 ligand (FasL)-induced apoptosis. J Exp Med. (1998) 188:88796. doi: 10.1084/jem.188.5.887

156. Keir ME, Liang SC, Guleria I, Latchman YE, Qipo A, Albacker LA, et al. Tissue expression of PD-L1 mediates peripheral T cell tolerance. J Exp Med. (2006) 203:883-95. doi: 10.1084/jem.20051776

157. Kaech SM, Hemby S, Kersh E, Ahmed R. Molecular and functional profiling of memory CD8 T cell differentiation. Cell. (2002) 111:837-51. doi: 10.1016/S0092-8674(02)01139-X

158. Kaech SM, Cui W. Transcriptional control of effector and memory CD8+ T cell differentiation. Nat Rev Immunol. (2012) 12:749-61. doi: $10.1038 /$ nri3307

159. Frebel H, Nindl V, Schuepbach RA, Braunschweiler T, Richter K, Vogel J, et al. Programmed death 1 protects from fatal circulatory failure during systemic virus infection of mice. J Exp Med. (2012) 209:2485-99. doi: $10.1084 /$ jem.20121015

160. Blackburn SD, Shin H, Haining WN, Zou T, Workman CJ, Polley A, et al. Coregulation of CD8 $+\mathrm{T}$ cell exhaustion by multiple inhibitory receptors during chronic viral infection. Nat Immunol. (2009) 10:29-37. doi: $10.1038 /$ ni. 1679

161. Wherry EJ, Barber DL, Kaech SM, Blattman JN, Ahmed R. Antigenindependent memory CD8 T cells do not develop during chronic viral infection. Proc Natl Acad Sci USA. (2004) 101:16004-9. doi: 10.1073/pnas.0407192101

162. Sen DR, Kaminski J, Barnitz RA, Kurachi M, Gerdemann U, Yates KB, et al. The epigenetic landscape of T cell exhaustion. Science. (2016) 354:1165-9. doi: 10.1126/science.aae0491

163. Ghoneim HE, Fan Y, Moustaki A, Abdelsamed HA, Dash P, Dogra P, et al. De novo epigenetic programs inhibit PD-1 blockade-mediated T cell rejuvenation. Cell. (2017) 170:142-157.e19. doi: 10.1016/j.cell.2017.06.007

164. Virgin HW, Wherry EJ, Ahmed R. Redefining chronic viral infection. Cell. (2009) 138:30-50. doi: 10.1016/j.cell.2009.06.036

165. Mumprecht S, Schürch C, Schwaller J, Solenthaler M, Ochsenbein AF. Programmed death 1 signaling on chronic myeloid leukemia-specific $\mathrm{T}$ cells results in T-cell exhaustion and disease progression. Blood. (2009) 114:1528-36. doi: 10.1182/blood-2008-09-179697
166. Francisco LM, Sage PT, Sharpe AH. The PD-1 pathway in tolerance and autoimmunity. Immunol Rev. (2010) 236:219-42. doi: 10.1111/j.1600-065X.2010.00923.x

167. Hill JA, Feuerer M, Tash K, Haxhinasto S, Perez J, Melamed R, et al. Foxp3 transcription-factor-dependent and -independent regulation of the regulatory T cell transcriptional signature. Immunity. (2007) 27:786-800. doi: 10.1016/j.immuni.2007.09.010

168. Walker LS. Treg and CTLA-4: two intertwining pathways to immune tolerance. J Autoimmun. (2013) 45:49-57. doi: 10.1016/j.jaut.2013.06.006

169. McCoy KD, Hermans IF, Fraser JH, Le Gros G, Ronchese F. Cytotoxic $\mathrm{T}$ lymphocyte-associated antigen 4 (CTLA-4) can regulate dendritic cell-induced activation and cytotoxicity of $\mathrm{CD} 8(+) \mathrm{T}$ cells independently of CD4(+) T cell help. J Exp Med. (1999) 189:1157-62. doi: 10.1084/jem.189.7.1157

170. Huard B, Gaulard P, Faure F, Hercend T, Triebel F. Cellular expression and tissue distribution of the human LAG-3-encoded protein, an MHC class II ligand. Immunogenetics. (1994) 39:213-7. doi: 10.1007/BF00 241263

171. Xu F, Liu J, Liu D, Liu B, Wang $M, H u ~ Z$, et al. LSECtin expressed on melanoma cells promotes tumor progression by inhibiting antitumor T-cell responses. Cancer Res. (2014) 74:3418-28. doi: 10.1158/0008-5472.CAN-13-2690

172. Wang J, Sanmamed MF, Datar I, Su TT, Ji L, Sun J, et al. Fibrinogenlike protein 1 is a major immune inhibitory ligand of LAG-3. Cell. (2019) 176(1-2):334-347.e12. doi: 10.1016/j.cell.2018.11.010

173. Huang CT, Workman CJ, Flies D, Pan X, Marson AL, Zhou G, et al. Role of LAG-3 in regulatory T cells. Immunity. (2004) 21:503-13. doi: 10.1016/j.immuni.2004.08.010

174. Zhou Q, Munger ME, Veenstra RG, Weigel BJ, Hirashima M, Munn DH, et al. Coexpression of Tim-3 and PD-1 identifies a CD8+ T-cell exhaustion phenotype in mice with disseminated acute myelogenous leukemia. Blood. (2011) 117:4501-10. doi: 10.1182/blood-2010-10-310425

175. Jin HT, Anderson AC, Tan WG, West EE, Ha SJ, Araki K, et al. Cooperation of Tim-3 and PD-1 in CD8 T-cell exhaustion during chronic viral infection. Proc Natl Acad Sci USA. (2010) 107:14733-8. doi: 10.1073/pnas.1009731107

176. Doering TA, Crawford A, Angelosanto JM, Paley MA, Ziegler CG, Wherry EJ. Network analysis reveals centrally connected genes and pathways involved in CD8+ T cell exhaustion versus memory. Immunity. (2012) 37:1130-44. doi: 10.1016/j.immuni.2012.08.021

177. Sciammas R, Davis MM. Blimp-1; immunoglobulin secretion and the switch to plasma cells. Curr Top Microbiol Immunol. (2005) 290:201-24. doi: 10.1007/3-540-26363-2_9

178. Crotty S, Johnston RJ, Schoenberger SP. Effectors and memories: Bcl-6 and Blimp-1 in T and B lymphocyte differentiation. Nat Immunol. (2010) 11:114-20. doi: 10.1038/ni.1837

179. Pearce EL, Mullen AC, Martins GA, Krawczyk CM, Hutchins AS, Zediak VP, et al. Control of effector CD8 $+\mathrm{T}$ cell function by the transcription factor Eomesodermin. Science. (2003) 302:1041-3. doi: 10.1126/science.1090148

180. Intlekofer AM, Takemoto N, Wherry EJ, Longworth SA, Northrup JT, Palanivel VR, et al. Effector and memory CD8+ T cell fate coupled by T-bet and eomesodermin. Nat Immunol. (2005) 6:1236-44. doi: 10.1038/ ni1268

181. Catakovic K, Klieser E, Neureiter D, Geisberger R. T cell exhaustion: from pathophysiological basics to tumor immunotherapy. Cell Commun Signal. (2017) 15:1. doi: 10.1186/s12964-016-0160-z

182. Gabrilovich D. Mechanisms and functional significance of tumourinduced dendritic-cell defects. Nat Rev Immunol. (2004) 4:941-52. doi: $10.1038 /$ nri1498

183. Dranoff G. Cytokines in cancer pathogenesis and cancer therapy. Nat Rev Cancer. (2004) 4:11-22. doi: 10.1038/nrc1252

184. Kryczek I, Zou L, Rodriguez P, Zhu G, Wei S, Mottram P, et al. B7H4 expression identifies a novel suppressive macrophage population in human ovarian carcinoma. J Exp Med. (2006) 203:871-81. doi: 10.1084/jem.20050930

185. Bennett MW, O’Connell J, O’Sullivan GC, Brady C, Roche D, Collins JK, et al. The Fas counterattack in vivo: apoptotic depletion of tumor-infiltrating lymphocytes associated with Fas ligand expression by human esophageal carcinoma. J Immunol. (1998) 160:5669-75. 
186. Fausch SC, Fahey LM, Da Silva DM, Kast WM. Human papillomavirus can escape immune recognition through Langerhans cell phosphoinositide 3-kinase activation. J Immunol. (2005) 174:7172-8. doi: 10.4049/jimmunol.174.11.7172

187. Yu P, Rowley DA, Fu YX, Schreiber H. The role of stroma in immune recognition and destruction of well-established solid tumors. Curr Opin Immunol. (2006) 18:226-31. doi: 10.1016/j.coi.2006.01.004

188. Dunn GP, Old LJ, Schreiber RD. The three Es of cancer immunoediting. Annu Rev Immunol. (2004) 22:329-60. doi: 10.1146/annurev.immunol.22.012703.104803

189. Hodi FS, O’Day SJ, McDermott DF, Weber RW, Sosman JA, Haanen JB, et al. Improved survival with ipilimumab in patients with metastatic melanoma. $N$ Engl J Med. (2010) 363:711-23. doi: 10.1056/NEJMoa1003466

190. Robert C, Ribas A, Wolchok JD, Hodi FS, Hamid O, Kefford R, et al. Anti-programmed-death-receptor-1 treatment with pembrolizumab in ipilimumab-refractory advanced melanoma: a randomised dosecomparison cohort of a phase 1 trial. Lancet. (2014) 384:1109-17. doi: 10.1016/S0140-6736(14)60958-2

191. Weber JS, D’Angelo SP, Minor D, Hodi FS, Gutzmer R, Neyns B, et al. Nivolumab versus chemotherapy in patients with advanced melanoma who progressed after anti-CTLA-4 treatment (CheckMate 037): a randomised, controlled, open-label, phase 3 trial. Lancet Oncol. (2015) 16:375-84. doi: 10.1016/S1470-2045(15)70076-8

192. Robert C, Schachter J, Long GV, Arance A, Grob JJ, Mortier L, et al. Pembrolizumab versus Ipilimumab in Advanced Melanoma. N Engl J Med. (2015) 372:2521-32. doi: 10.1056/NEJMoa1503093

193. Ribas A, Puzanov I, Dummer R, Schadendorf D, Hamid O, Robert C, et al. Pembrolizumab versus investigator-choice chemotherapy for ipilimumabrefractory melanoma (KEYNOTE-002): a randomised, controlled, phase 2 trial. Lancet Oncol. (2015) 16:908-18. doi: 10.1016/S1470-2045(15)00083-2

194. Gong J, Chehrazi-Raffle A, Reddi S, Salgia R. Development of PD-1 and PDL1 inhibitors as a form of cancer immunotherapy: a comprehensive review of registration trials and future considerations. J Immunother Cancer. (2018) 6:8. doi: 10.1186/s40425-018-0316-z

195. Fehrenbacher L, Spira A, Ballinger M, Kowanetz M, Vansteenkiste J, Mazieres J, et al. Atezolizumab versus docetaxel for patients with previously treated non-small-cell lung cancer (POPLAR): a multicentre, openlabel, phase 2 randomised controlled trial. Lancet. (2016) 387:1837-46. doi: 10.1016/S0140-6736(16)00587-0

196. Rittmeyer A, Barlesi F, Waterkamp D, Park K, Ciardiello F, von Pawel $\mathrm{J}$, et al. Atezolizumab versus docetaxel in patients with previously treated non-small-cell lung cancer (OAK): a phase 3, open-label, multicentre randomised controlled trial. Lancet. (2017) 389:255-65. doi: 10.1016/S0140-6736(16)32517-X

197. Rosenberg JE, Hoffman-Censits J, Powles T, van der Heijden MS, Balar AV, Necchi A, et al. Atezolizumab in patients with locally advanced and metastatic urothelial carcinoma who have progressed following treatment with platinum-based chemotherapy: a single-arm, multicentre, phase 2 trial. Lancet. (2016) 387:1909-20. doi: 10.1016/S0140-6736(16)00561-4

198. Balar AV, Galsky MD, Rosenberg JE, Powles T, Petrylak DP, Bellmunt J, et al. Atezolizumab as first-line treatment in cisplatin-ineligiblepatients with locally advanced and metastatic urothelial carcinoma: a singlearm, multicentre, phase 2 trial. Lancet. (2017) 389(10064):67-76. doi: 10.1016/S0140-6736(16)32455-2

199. Massard C, Gordon MS, Sharma S, Rafii S, Wainberg ZA, Luke J, et al. Safety and efficacy of durvalumab (MEDI4736), an Anti-programmed cell death ligand-1 immune checkpoint inhibitor, in patients with advanced urothelial bladder cancer. J Clin Oncol. (2016) 34:3119-25. doi: 10.1200/JCO.2016.67.9761

200. Apolo AB, Infante JR, Balmanoukian A, Patel MR, Wang D, Kelly $\mathrm{K}$, et al. Avelumab, an Anti-Programmed Death-Ligand 1 Antibody, In Patients With Refractory Metastatic Urothelial Carcinoma: Results From a Multicenter, Phase Ib Study. J Clin Oncol. (2017) 35:2117-24. doi: 10.1200/JCO.2016.71.6795

201. Kaufman HL, Russell J, Hamid O, Bhatia S, Terheyden P, D'Angelo $\mathrm{SP}$, et al. Avelumab in patients with chemotherapy-refractory metastatic Merkel cell carcinoma: a multicentre, single-group, open-label, phase 2 trial. Lancet Oncol. (2016) 17:1374-85. doi: 10.1016/S1470-2045(16) 30364-3

202. Boutros C, Tarhini A, Routier E, Lambotte O, Ladurie FL, Carbonnel F, et al. Safety profiles of anti-CTLA-4 and anti-PD-1 antibodies alone and in combination. Nat Rev Clin Oncol. (2016) 13:473-86. doi: 10.1038/nrclinonc. 2016.58

203. Nishimura H, Minato N, Nakano T, Honjo T. Immunological studies on PD-1 deficient mice: implication of PD-1 as a negative regulator for $\mathrm{B}$ cell responses. Int Immunol. (1998) 10:1563-72. doi: 10.1093/intimm/10.10.1563

204. Haratani K, Hayashi H, Chiba Y, Kudo K, Yonesaka K, Kato R, et al. Association of immune-related adverse events with nivolumab efficacy in non-small-cell lung cancer. JAMA Oncol. (2018) 4:374-378. doi: 10.1001/jamaoncol.2017.2925

Conflict of Interest Statement: SP receives research funding from: MedImmune, Genentech, Pfizer, Amgen, Xcovery, Lilly, Bristol-Myers Squibb, and he receives speaking fees from: Boehringer Ingelheim, Merck. EC reports research funding from Pfizer, Merck, AstraZeneca, and Bristol-Myers Squibb outside the submitted work. AS reports research funding and honoraria from Pfizer and Varian Medical Systems, consultant fees from Astrazeneca, and other fees from Raysearch and Merck. The funder played no role in the study design, the collection, analysis or interpretation of data, the writing of this paper or the decision to submit it for publication.

The remaining authors declare that the research was conducted in the absence of any commercial or financial relationships that could be construed as a potential conflict of interest.

Copyright (C) 2019 Guram, Kim, Wu, Sanders, Patel, Schoenberger, Cohen, Chen and Sharabi. This is an open-access article distributed under the terms of the Creative Commons Attribution License (CC BY). The use, distribution or reproduction in other forums is permitted, provided the original author(s) and the copyright owner(s) are credited and that the original publication in this journal is cited, in accordance with accepted academic practice. No use, distribution or reproduction is permitted which does not comply with these terms. 